\title{
OVERSTORY STRUCTURE DRIVES FINE-SCALE COUPLING OF UNDERSTORY LIGHT AND VEGETATION IN TWO TEMPERATE RAINFOREST FLOODPLAINS
}

\begin{tabular}{|r|l|}
\hline Journal: & Canadian Journal of Forest Research \\
\hline Manuscript ID & cjfr-2016-0466.R1 \\
\hline Date Submitted by the Author: & 12-Apr-2017 \\
\hline Complete List of Authors: & $\begin{array}{l}\text { Giesbrecht, Ian; Simon Fraser University, School of Resource and } \\
\text { Environmental Management; Hakai Institute, } \\
\text { Saunders, Sari; BC Ministry of Forests } \\
\text { MacKinnon, Andy; BC Ministry of Forests and Range; Current address, 504 } \\
\text { Witty Beach Road } \\
\text { Lertzman, Ken; Simon Fraser University, School of Resource and } \\
\text { Environmental Management }\end{array}$ \\
\hline Keyword: & $\begin{array}{l}\text { riparian forest, canopy gaps, light transmission, understory vegetation, } \\
\text { temperate rainforest }\end{array}$ \\
\hline $\begin{array}{r}\text { Is the invited manuscript for } \\
\text { consideration in a Special } \\
\text { Issue? : }\end{array}$ & N/A \\
\hline &
\end{tabular}




\section{OVERSTORY STRUCTURE DRIVES FINE-SCALE COUPLING OF UNDERSTORY LIGHT AND VEGETATION IN TWO TEMPERATE RAINFOREST FLOODPLAINS}

Ian J.W. Giesbrecht ${ }^{\mathrm{a}, \mathrm{b},}$, Sari C. Saunders ${ }^{\mathrm{c}}$, Andy MacKinnon ${ }^{\mathrm{c}, \mathrm{d}}$, and Ken P. Lertzman $^{\mathrm{a}, \mathrm{b}}$

${ }^{\text {a }}$ School of Resource and Environmental Management, Simon Fraser University, 8888 University Drive, Burnaby, BC, V5A 1S6, Canada.

${ }^{\mathrm{b}}$ Current address: Hakai Institute, PO Box 309, Heriot Bay, BC, V0P 1H0, Canada.

$14{ }^{\mathrm{c}}$ BC Ministry of Forests, Lands and Natural Resource Operations, 103-2100 Labieux Rd., 15 Nanaimo, BC, V9T 6E9, Canada.

16 d Current address: 504 Witty Beach Road, Metchosin, BC, V9C 4H8, Canada. 


\section{Abstract}

21 Riparian ecosystems - particularly floodplains - of temperate rainforest regions are productive,

22 diverse, functionally important and socially valued, yet we lack key information about their

23 structure and function to guide conservation and management. In two one-hectare floodplain

24 sites in coastal British Columbia, we mapped tree locations, classified gap processes, and

25 described understory vegetation and light transmission on a systematic grid. We used

26 hemispheric photography and spatial interpolation to map understory light and we examined how

27 environmental heterogeneity affects understory vegetation. Understory light levels are high

28 (overall median $18 \%$ full sun) but vary appreciably over short distances $(0.5 \%$ to $19 \%$ full sun

29 over $14 \mathrm{~m}$ ). Understory composition varies in relation to light transmission, indicating that

30 overstory structure drives fine-scale spatial structure in the understory plant community.

31 Overstory trees appear to create "shade refuges" from competition with dominant shrubs. Shrub

32 cover increases with light and may also play a role in maintaining persistent canopy openings by

33 slowing conifer recruitment. Despite substantial differences in age and development history,

34 each stand exhibits fine-scale spatial coupling of understory light and vegetation. Management

35 practices encouraging structural complexity may accelerate development of similar processes

36 and patterns to restore floodplain function in high-density second growth stands.

38 Keywords: riparian forest; canopy gaps; light transmission; understory vegetation; coastal 39 temperate rainforest. 


\section{Introduction}

42 Understanding how disturbance and other stand development processes shape overstory and

43 understory vegetation is central to forest ecology (Watt 1947, Brokaw 1985, Franklin et al.

44 2002). As a stand matures, small-scale canopy disturbances and tree growth generate complex

45 horizontal and vertical structure (Spies and Franklin 1988, Lertzman et al. 1996, Franklin et al.

46 2002). Such small-scale canopy disturbances increase the availability and heterogeneity of

47 understory resources such as light (Runkle 1984, Canham et al. 1990), with consequences for the

48 productivity, composition, and diversity of understory vegetation (Denslow 1985, Mladenoff

49 1990, McCarthy 2000). Conversely, understory vegetation may influence tree recruitment, gap

50 filling, and stand dynamics (Spies and Franklin 1989, Royo and Carson 2006). For example, in

51 some forests Rubus spectabilis Pursh invades forest openings, inhibits conifer regeneration, and

52 may be able to maintain persistent canopy openings (Henderson 1978, Minore and Weatherly

53 1994, Tappeiner et al. 2001). Similar processes have been observed with Acer circinatum Pursh

54 (McGhee 1996) among other understory plants (Royo and Carson 2006) - hereafter referred to as

55 the persistent gap hypothesis.

56 Dividing the forest into coarse classes of gap and closed canopy provides a first approximation

57 of canopy openness and within-stand resource heterogeneity. However, despite the sometimes

58 stark differences in canopy openness between gaps and closed canopy patches (e.g., Levey

59 1988), the fine-scale patterns and processes of light transmission are often more complex than

60 can be adequately described by this dichotomy (Lieberman et al. 1989). This is particularly true

61 in higher latitude temperate forests where the ubiquitous effects of topography (Canham et al.

62 1990) are accentuated by tall canopies and sub-canopy layers, resulting in the footprint of light 
63 transmission sometimes being displaced substantially from the actual canopy opening (Van Pelt

64 and Franklin 2000). The original binary gap concepts and methods also begin to break down for

65 large opennings (e.g., $1000 \mathrm{~m}^{2}$ according to Schliemann and Bockheim 2011) and very open

66 forests (Zhu et al. 2015). Treating the distribution of understory light as a continuous variable

67 increases our ability to resolve and interpret the spatial patterns of light and potential drivers of

68 understory vegetation (Lieberman et al. 1989, Frelich et al. 2003).

69 Riparian forests of the Coastal Temperate Rainforest (CTR) of North America (Schoonmaker et

70 al. 1997) are among the most productive forests on the continent, with mature floodplain stands

71 attaining among the highest canopy volumes on earth (Van Pelt et al. 2006). These forests

72 support high understory vegetation biomass, tend to have higher plant species diversity than

73 upland forests (Gregory et al. 1991; Pabst and Spies 1998), and support vigorous populations of

74 culturally-important plant species (Turner 1998). Floodplain forests in the CTR also provide

75 valuable habitat for a diversity of terrestrial wildlife, and interact with river systems in ways that

76 create and maintain salmon habitat and linkages between terrestrial and marine ecosystems

77 (Naiman et al. 2010). Floodplain forests also have significant timber value. In the CTR of British

78 Columbia, floodplain forests have been preferentially harvested compared to upland forests

79 (Pearson 2010) due to their productivity, timber quality, and accessibility. The BC Conservation

80 Data Centre has assigned a conservation status of imperiled or higher to most coniferous

81 floodplain communities in the CTR (BC CDC 2017). Despite the ecological significance and

82 conservation status of these forests, we know little about the details of canopy structure and fine-

83 scale interactions with understory light and vegetation, especially in the more Northerly portions

84 of the CTR in BC and Alaska. 
85 In this paper, we examined two large (1 ha), intensively surveyed forest plots in conifer-

86 dominated floodplain stands of the CTR along the BC coast to characterize stand structure,

87 assess the spatial heterogeneity of understory light regimes, and analyze the role of light and

88 other environmental variables in driving within-stand vegetation patterns and processes.

\section{Materials and Methods}

\section{Site descriptions}

91 We studied two sites in the submontane variant of the very wet maritime subzone of the Coastal

92 Western Hemlock zone (CWHvm1) of the British Columbia coast (Meidinger and Pojar 1991)

93 (Figure 1 and Table 1). Mean annual precipitation for the CWHvm1 is $2682(1555-4387) \mathrm{mm}$,

94 mean temperature of the warmest month is $16.3(13.8-18.8){ }^{\circ} \mathrm{C}$, and growing degree-days

95 average 1633 (1313-2011) days (Green and Klinka 1994) (Table 1). These sites were selected as

96 representative examples of floodplain forests in the CTR as part of a larger network of long-term

97 old-growth monitoring plots (MacKinnon et al. 2010).

98 The Kitlope site is located near the outlet in a $2758 \mathrm{~km}^{2}$ unlogged watershed on the North Coast

99 of British Columbia at the head of the Gardner Canal. The Carmanah site is on the Southwest

100 coast of Vancouver Island and located more centrally within a $68 \mathrm{~km}^{2}$ watershed. Both the

101 Kitlope and Carmanah stands are in relatively flat valley-bottom sites classified as high bench

102 floodplains with the corresponding Picea sitchensis - Rubus spectabilis Plant Association (Green

103 and Klinka 1994). Typical high bench floodplains are classified as infrequently flooded sites

104 (return interval $>5 \mathrm{yr}$ ) (Green and Klinka 1994). Soils at the two sites are derived from fine

105 textured alluvium (>70 cm depth) with varying degrees of humus development. Across the

106 Kitlope site there was evidence of a recent low energy flood: during sampling there were silt 
107 lines up to $1 \mathrm{~m}$ on tree boles and $\sim 1 \mathrm{~cm}$ of fresh silty alluvium over most of the forest floor,

108 under only $\sim 0.5 \mathrm{~cm}$ of organic litter. Understory vegetation in each site is characterized by high

109 total shrub layer cover (median $>75 \%$ ) dominated by Rubus spectabilis (median $\geq 55 \%$ ). In each

110 stand, the largest overstory trees are Picea sitchensis (Bong.) Carr., with several individuals

111 taller than $60 \mathrm{~m}$ in height (max 62 to $93 \mathrm{~m}$ ). Based on coring a sample of main canopy trees,

112 stand age at Kitlope is at least 95 years. Stand age at Carmanah is at least 350 years, based on a

113 core from a $50 \mathrm{~m}$ tall $P$. sitchensis (the largest trees could not be cored with the available

114 increment borer). Floodplain forests in the CTR can develop a degree of old-growth character

115 much earlier than upland forests (Van Pelt et al. 2006), and despite differences in age, both the

116 Kitlope and Carmanah stands exhibit attributes of "old-growthness" (Wells et al. 1998, Franklin

117 et al. 2002) including very large trees, open and structurally diverse canopies, and productive

118 understory vegetation.

\section{Sampling}

120 Each site consists of a $100 \mathrm{~m} \times 100 \mathrm{~m}$ (1 ha) plot in which all trees $\geq 5 \mathrm{~cm}$ diameter at breast

121 height were mapped and measured (Figure S1, Supplementary material ${ }^{1}$ ). We sampled

122 understory vegetation in 25 subplots $(2 \mathrm{~m} \mathrm{x} 2 \mathrm{~m})$ systematically distributed on a regular grid in

123 each site and took hemispheric canopy photographs at 50 points on a regular grid, including in

124 all vegetation subplots. Subplots had a minimum separation of $20 \mathrm{~m}$ and canopy photos had a

125 minimum separation of $14 \mathrm{~m}$. In subplots, we estimated percent foliar cover of all shrubs and

126 herbs by species, based on a vertical projection to the ground.

\footnotetext{
${ }^{1}$ Supplementary material for this article is available through the journal Web site.
} 
127 We recorded canopy cover class (closed canopy, expanded gap, canopy gap) following the

128 methods of Lertzman and Krebs (1991). Using this method allowed us to compare our sites to

129 other CTR forests in the literature. An opening in the forest canopy was defined as a canopy gap

130 if it exceeded $1 / 2$ an average tree crown width in diameter. Expanded gap refers to the region

131 from a canopy gap boundary (crown margins) to a line connecting the boles of trees whose

132 canopies define the canopy gap. Closed canopy refers to the area beyond the boundary of an

133 expanded gap. Trees $\geq 10 \mathrm{~m}$ tall, with $\mathrm{DBH} \geq 22 \mathrm{~cm}$, were considered canopy trees, following

134 Lertzman and Krebs (1991). More recent methods for defining canopy gaps - particularly

135 minimum and maximum gap sizes - depend on the height of canopy trees surrounding a gap

136 (Zhu et al. 2015). However, these more complex techniques still result in a dichotomous

137 characterization of canopy openness and would prevent direct comparison of our results to

138 earlier studies in the region.

139 We defined gap origin (developmental, edaphic, unknown origin) following the methods of

140 Lertzman et al. (1996). Gaps of developmental origin have evidence of a gapmaker: a tree that

141 died to create the gap. Edaphic origin gaps are openings associated with edaphic conditions (e.g.,

142 stream channel, rock outcrop, or thin soil); gapmakers may be present but cannot, on their own,

143 explain the opening (Lertzman et al. 1996). Gaps of unknown origin are openings not obviously

144 associated with tree mortality or edaphic conditions.

145 To estimate light transmission to the understory as a continuous variable, we took hemispheric

146 canopy photographs above the shrub layer at each photo point, using a Cannon 5D digital SLR

147 camera and a Sigma 8-mm fisheye lens. Photos were taken above the shrub layer to ensure a

148 clear view of the overstory (lens height $180 \pm 5 \mathrm{~cm}$ at Carmanah; $195 \pm 5 \mathrm{~cm}$ at Kitlope). The

149 lens was leveled and oriented north. We registered the north position in the image with a small 
150 LED light mounted on a lens plate. Shrub foliage above the lens was pulled away from the field

151 of view. Auto exposure bracketing was generally used to record images at three exposures - we

152 selected the highest contrast image that still maintained small gaps near the horizons (Frazer et

153 al. 2000a).

154 We recorded additional environmental characteristics that might influence plants in each

155 vegetation subplot. We visually estimated percentage ground covered by organic forest floor $(\geq 1$

$156 \mathrm{~cm}$ organic layer), mineral soil ( $<1 \mathrm{~cm}$ organic layer), coarse woody debris, and other substrates.

157 We recorded the thickness of organic horizons (L, F, and $\mathrm{H}$ ) and the Ah layer (mineral soil

158 enriched in humified organic matter). Substrate, soil horizon, and textural classes (by hand

159 texturing) were defined following BC Ministry of Forests and BC Ministry of Environment

160 Lands and Parks (1998).

161 Data preparation and processing

162 We used Gap Light Analyzer Version 2.0 (GLA 2.0) (Frazer et al. 2000a) to estimate light

163 transmission, canopy openness, and leaf area index from canopy photographs. Site-specific

164 configurations were used for elevation, latitude, longitude, and growing season, and subplot

165 specific configurations for slope, aspect, and topographic shading. To increase the accuracy of

166 light estimates, we calculated monthly cloudiness index, spectral fraction, and beam fraction

167 based on solar radiation data collected at the most representative coastal meteorological station

168 with solar radiation data (Port Hardy) using equations provided with GLA (Frazer et al. 1999).

169 Growing season start and end dates were inferred from a combination of expert opinion (K.

170 Lertzman and A. MacKinnon) and local climate normals for growing degree-days (degree-days

171 above $5^{\circ} \mathrm{C}$ ) and the frost-free period. Finally, we calibrated GLA for the Sigma 8-mm F3.5 
172 fisheye lens by using 24 calibration data points provided by Sigma Corporation to define a

173 custom projection transformation in GLA (Frazer et al. 1999).

174 GLA requires a manual image thresholding procedure to designate each pixel as sky or non-sky.

175 We used two thresholding rules. First, even the lightest vegetation tones were designated as non176 sky. Second, we used regional thresholding (Frazer et al. 1999) to avoid loss of smaller gaps near 177 the horizon, or conversely, loss of fine foliage adjacent to open sky. To provide an indication of 178 precision with light transmission estimates, we re-processed GLA estimates from nine 179 photographs. Differences in percentage full sun estimates between runs were $0.31 \%$ full sun on 180 average and were never more than $3 \%$ full sun.

181 As measures of subplot species diversity, we calculated richness (S), evenness (E), and 182 dominance (Ls) using PC-ORD 5 (McCune and Mefford 2006). Species richness is the number 183 of species. Evenness - how evenly cover is distributed among species - is calculated as $\mathrm{E}=\mathrm{H} /$ $184 \ln (\mathrm{S})$ (Pielou 1969) where $\mathrm{H}$ is Shannon diversity index $\mathrm{H}=-\sum\left(p_{i} \ln \left(p_{i}\right)\right)$ and $p_{i}$ is the proportion 185 of cover in the $i$ th species $\left(p_{i}=n_{i} / N\right)$ (Gurevitch et al. 2002). Dominance expresses the probability 186 that two randomly chosen individuals belong to the same species, calculated as Ls $=\mathrm{D}-1$

187 (Gurevitch et al. 2002) where D is Simpson's diversity index D $=1-\sum\left(p_{i}^{2}\right)$.

188 We calculated derived measures of edaphic conditions for each subplot. Distance to the nearest 189 waterbody (small channels) was estimated from a fine-scale field-drawn map of waterbodies. We 190 used the SPAW Model with Soil Water Characteristics program (available online:

191 http://hydrolab.arsusda.gov/SPAW/SPAWDownload.html) to estimate percentage clay,

192 percentage sand, saturated hydraulic conductivity (Ks: cm/hr) and Plant Available Water (PAW:

$193 \mathrm{~cm}^{3}$ water $/ \mathrm{cm}^{3}$ soil) from field estimates of soil textural class and coarse fragment content. The

194 SPAW model uses the empirical equations of Saxton and Rawls (2006). 
195 Some of the systematically sampled locations were not included in the analysis because they

196 were rare (undersampled) and distinct microsites or were topographically elevated above the

197 floodplain. At Carmanah, this included three subplots (eight photo points) on an elevated terrace

198 landform, with different edaphic conditions than the floodplain; and two subplots in a fluvial

199 channel lacking soil or vegetation. For vegetation analyses, we also omitted a subplot where the

200 herbaceous layer and forest floor had been almost entirely buried by recent flood sediments.

201 Furthermore, a recent wind disturbance at Carmanah substantially affected three subplots via the

202 direct influence of overstory removal and slash accumulation. These subplots were subjected to a

203 sensitivity analysis and removed from subsequent vegetation analysis - an effort to control for

204 the temporal lag of understory vegetation response to canopy disturbance (e.g., Nicotra et al.

205 1999). At Kitlope, one subplot was omitted because it was in a small waterbody.

\section{Analysis}

207 We used ESRI's ArcGIS to generate maps of the spatial distribution of understory light and

208 overstory trees. We used a tension spline interpolation to visualize light gradients between

209 sample points. This interpolation method creates a smooth, minimum curvature surface that

210 passes exactly through the data points.

211 We used linear correlation analysis to examine relationships among measures of light

212 transmission, vegetation structure, and diversity. Because a number of the vegetation and

213 environment variables in the dataset show positive spatial autocorrelation at $20 \mathrm{~m}$ (Giesbrecht

214 2010), potentially inflating Type I error rate for the correlation analysis (Legendre and Legendre

215 1998), we used Dutilleul's procedure in PASSaGE v2 (Rosenberg 2009) to correct for the effect

216 of spatial autocorrelation on $t$-tests of correlation significance (Dutilleul 1993). 
217 Non-metric multidimensional scaling (NMS) (Mather 1976, Kruskal 1964) was used to describe

218 variation in species composition on multivariate axes. We conducted the NMS with the Sørensen

219 (Bray-Curtis) distance measure, using the autopilot mode in PC-ORD 5 (McCune and Mefford

220 2006) with the "slow and thorough" setting. To aid interpretation, we rotated the resulting

221 ordination graphs to maximize the correlation of Axis 1 with percentage full sun (McCune and

222 Grace 2002). Axes 2 and 3 thus describe compositional variation that is virtually independent of

223 light. After applying the rotations, we used correlation coefficients and ordination diagrams to

224 describe the compositional axes in terms of species abundances and to examine relationships

225 between compositional axes and environmental variables. We assessed the quality of the NMS

226 solution, based on the proportion of variance in the original data represented by each axis and the

227 three axes cumulatively. This proportion was computed using the Sørensen (Bray-Curtis)

228 distance measure.

229 Prior to conducting the NMS ordination, we prepared the community dataset following McCune

230 and Grace (2002). We deleted rare species: those with less than five occurrences. We applied a

231 relativization to species abundances because our interest is more in compositional than structural

232 changes. Specifically, we relativized by species maximum, which balances the emphasis on

233 dominant species and species with lower abundances. Finally, we applied an arcsine square root

234 transformation to all species to reduce the positive skew that characterizes community data.

\section{Results}

\section{Stand composition and development}

237 Both stands have a small number of large to very large Picea sitchensis trees - presumably the 238 pioneer cohort (Figure 2). Both stands have a larger number of small to intermediate sized trees, 
239 including some shade intolerant deciduous trees in the smaller $(<50 \mathrm{~cm})$ size classes. However,

240 understory tree densities are very low compared to mature and old-growth forests in upland

241 (zonal) sites of the same biogeoclimatic variant in BC (BC Ministry of Forests 2001), which

242 have respectively 301 and 414 mean stems per hectare in the 7.5-17.5 cm diameter classes. By

243 contrast, Kitlope has 27 stems and Carmanah has 55 stems, in this size range. Overall stem

244 densities (117 at Kitlope; 241 at Carmanah) are also low compared to zonal forests of this

245 subzone (720 and 790 for old-growth and mature stands respectively).

246 Despite these broad similarities of Kitlope and Carmanah, the two stands differ substantially in

247 other aspects of composition and tree size structure, suggesting different developmental histories.

248 The diameter distribution of live trees at Carmanah follows an approximate negative exponential

249 distribution as expected for an old-growth forest, with shade tolerant Tsuga heterophylla

250 abundant in most size classes $<100 \mathrm{~cm}$ diameter and Picea sitchensis virtually absent below 100

$251 \mathrm{~cm}$. At Kitlope, tree densities are much lower in the small to intermediate $(<90 \mathrm{~cm})$ size classes,

252 Picea sitchensis is present in the broad range of size classes and other conifers are nearly absent,

253 suggesting a stand with less understory reinitiation of shade tolerant conifers than evident at

254 Carmanah. Snags are abundant at Carmanah, including some very large $(>100 \mathrm{~cm}$ diameter)

255 individuals (Figure S2, Supplementary material), which are mostly Tsuga heterophylla or

256 unknown conifers, indicating main canopy tree mortality events that would have meaningfully

257 increased light transmission to the understory. By contrast, there is little evidence of canopy tree

258 mortality at Kitlope, with few snags $>50 \mathrm{~cm}$ diameter.

\section{Gap structure and light transmission}

260 Closed canopy microsites are rare at both Kitlope $(8 \%$, of $n=50)$ and Carmanah $(2 \%$, of $n=42)$.

261 At least $92 \%$ of each site is in expanded gap or canopy gap (Figure 3). At Carmanah, 27\% of 
262 canopy gap microsites and $12 \%$ of expanded gap microsites are located in an area of recent

263 windthrow (presumably the winter before sampling, when extensive wind disturbance occurred

264 across the BC south coast). Overall, most gap areas at Carmanah are developmental in origin

$265(83 \%)$ - clearly associated with a dead tree - while the remainder $(17 \%)$ have edaphic origins

266 (Figure 3Error! Reference source not found.). By contrast, few gap microsites at Kitlope are

267 clearly associated with tree mortality (2\%) or edaphic factors (9\% of gaps).

268 Kitlope and Carmanah each have median 18\% of the PAR that would be available under an

269 unobstructed view of the sky (hereafter “\% full sun”) (Table 2). At Kitlope, mean light

270 transmission is $18.8 \pm 4.8 \%$ full sun, ranging from 10.0 to $33.9 \%$. At Carmanah, mean light

271 transmission is $17.9 \pm 5.7 \%$, and varies from to 9.0 to $28.3 \%$ (Figure 4). Carmanah has more

272 microsites with $<12.5 \%$ full sun and a bi-modal distribution of light availability, which taken

273 together result in greater variation among microsites than at Kitlope (Figure 4). Light

274 transmission at Kitlope is unimodal and more strongly concentrated around the mean.

275 Understory light is spatially variable within each one-hectare site. Light transmission estimates at 276 adjacent sample points (14 m separation) range from very similar ( $\pm 0.5 \%$ full sun) to very

277 different $( \pm 19 \%$ full sun). These spatial gradients are also visually represented with the contour

278 shading in Figure 5, based on interpolated light values between photo locations. Our understory

279 light maps show the end result of solar radiation passing through the overstory filter. The vertical 280 and horizontal distribution of forest biomass (represented in a basic way by mapped tree

281 locations, tree diameters, and canopy cover classes) interacts with directional incoming radiation 282 to produce the observed spatial pattern of light transmission. 


\section{Species composition in relation to environmental heterogeneity}

284 At both sites, fine-scale spatial variation of the understory plant community is organized along

285 recognizable compositional gradients. The autopilot NMS procedures recommended three

286 compositional axes for each site. At Kitlope, the three axis solution represents $79 \%$ of variance

287 in the original data, has a final stress of 14.05 , final instability $<0.00001$, and is significantly

288 stronger than expected by chance $(P=0.004)$. At Carmanah, the three axis solution represents

$28990 \%$ of variance in the original data, has a final stress of 8.32 , final instability $<0.00001$, and is

290 significantly stronger than expected by chance $(P=0.004)$. The NMS method produces axes

291 defined by vegetation composition alone, without direct incorporation of environmental

292 variables.

293 The strongest compositional axis at Kitlope (Axis 1) is best related to light transmission, with a

294 strong linear correlation $(r=0.72$; Table 3 and Figure 6$)$. There is only evidence of weak

295 associations between Axis 1 and the edaphic properties we measured such as forest floor

296 thickness or mineral soil texture (all $|r|<0.33$ ). Axis 1 represents $41 \%$ of the variance in the

297 original data and describes a compositional gradient exemplified by Oplopanax horridus,

298 Dryopteris expansa, and Osmorhiza berteroi associated with lower light levels and Ribes

299 bracteosum and Circaea alpina associated with higher light levels. See Supplementary material

$300 \mathrm{~S} 3$ for a more complete examination of species associated with light. Axis 2 and Axis 3 represent

$301 \quad 17 \%$ and $21 \%$ of the variance in the original data, respectively, and are unrelated to measured

302 edaphic variables (Table 3 and Figure 6).

303 The strongest compositional axis at Carmanah (Axis 1) is also best related to light transmission

$304(r=0.57)$, with only weak correlations with the edaphic properties we measured $($ all $|r|<0.35)$

305 (Table 4 and Figure 6). Axis 1 at Carmanah represents $34 \%$ of variance in the original data and 
306 describes a compositional gradient characterized by increasing cover of Rubus spectabilis and

307 Ribes bracteosum with increasing light availability, with decreasing cover of Blechnum spicant

308 among other species (Supplementary material S3) as light increases.

309 Axis 2 at Carmanah represents $27 \%$ of variance in the original data and is most strongly

310 correlated with substrate properties, particularly clay content $(r=0.67)$ and humus thickness $(r=-$

$3110.56)$, independent of light $(r=-0.01)$. Axis 3 at Carmanah represents $28 \%$ of variance in the

312 original data and is not meaningfully correlated with the edaphic variables we measured (Table

$3134)$.

314 Cover of understory layers and species diversity in relation to light

315 The covers of herb and shrub layers show differing degrees of correlation with light transmission

316 through the canopy. As expected, shrub cover is positively correlated with light transmission at

317 both sites $\left(r=0.48, P_{D u t}=0.02\right.$ Kitlope; $r=0.63, P_{D u t}=0.008$ Carmanah) (Table 5) after stratifying

318 to exclude the recent windthrow. This is consistent with a hypothesis of light-limited shrub

319 biomass. Herb cover, by contrast, is not significantly correlated with light, in either site,

320 suggesting that shrubs play in important role in mediating herb response to overstory light

321 transmission. Indeed, herb cover decreases significantly with Rubus spectabilis cover at Kitlope

$322\left(r=-0.41, P_{D u t}=0.04\right)$.

323 Rubus spectabilis cover shows a strong and significant positive correlation with light

324 transmission at Carmanah $\left(r=0.79, P_{\text {Dut }}=0.001\right)$ but, surprisingly, not at Kitlope $(r=0.24$,

$\left.325 P_{\text {Dut }}=0.25\right)($ Table 5). However, $R$. spectabilis cover is positively correlated with light at Kitlope

326 after controlling for the cover of other shrubs using partial correlation (Legendre and Legendre

327 1998) $(r=0.52, P=0.011)$. Thus, at Kitlope, $R$. spectabilis response to abundant light may be 
328 mediated by other factors such as competition with other shrub species. Indeed, further

329 examination reveals that Ribes bracteosum, and sometimes also Sambucus racemosa, are more

330 abundant than $R$. spectabilis in five of the six subplots that are bright yet have low R. spectabilis

331 cover. In all other subplots, $R$. spectabilis is the most abundant of the three species. Furthermore,

332 R. spectabilis was not completely absent from any subplot at Kitlope, suggesting that even in the

333 darkest microsites in this stand, light may not be limited enough to exclude this plant.

334 Point level species diversity varies inversely with Rubus spectabilis cover. Increasing cover of $R$.

335 spectabilis is positively correlated with dominance (Ls) at both Kitlope $\left(r=0.71, P_{D u t}=<0.001\right)$

336 and Carmanah $\left(r=0.73, P_{D u t}=0.002\right)$. Correspondingly, $R$. spectabilis cover is negatively

337 correlated with species eveness (E) at both sites (Table 5). At Carmanah, Ls has a strong positive

338 correlation with light $\left(r=0.72, P_{D u t}=0.004\right)$ and $\mathrm{E}$ has a negative correlation with light $(\mathrm{r}=-0.64$,

$\left.339 P_{\text {Dut }}=0.01\right)$. Point diversity is not directly related to light transmission at Kitlope. Species

340 richness does not show strong correlations with light or $R$. spectabilis in either site.

341 Recent conifer regeneration is limited at both sites. At Kitlope, no conifers were observed in the

342 low shrub layer $(<2 \mathrm{~m})$ of subplots, and seedlings (all Picea sitchensis) were reported in only 5

343 subplots (21\%). At Carmanah, no seedlings and only one conifer $<2 \mathrm{~m}$ were observed across all

344 subplots and most of the understory Tsuga heterophylla outside of subplots are found growing on $345 \operatorname{logs}$

346 Discussion

347 Openness: canopy openness and light transmission in context

348 Canopy structure in these floodplain forests is characterized by a high degree of canopy openness

349 and light transmission compared to a broad range of tropical to temperate forests (Supplementary 
350 material S4). Both Kitlope and Carmanah have high overall light transmission rate (median 18\%

351 full sun) and canopy openness (11.0 to $11.6 \%$ ) compared to a range of other riparian and upland

352 sites in the CTR (Frazer et al. 2000b, Sarr and Hibbs 2007a), although similar openness estimates

353 have been reported for some drier (rainshadow), non-riparian forests of the CTR on eastern

354 Vancouver Island (Frazer et al. 2000b). Similarly, our study sites have very high incidence of

355 locations classed as canopy gap and expanded gap (92\% at Kitlope, 98\% at Carmanah) compared

356 to the Tofino Creek watershed on West Vancouver Island (56\%; Lertzman et al. 1996) and

357 snowy subalpine rainforests on the BC south coastal mainland (70\%; Lertzman and Krebs 1991).

358 By contrast, mean light transmission at Carmanah and Kitlope is markedly lower than reported

359 for a number of old-growth boreal forests in Quebec (27\%; Bartemucci et al. 2006) and northern

360 BC (26.7\%; Bartemucci et al. 2002).

361 Such comparison of floodplain canopy openness and light transmission to a broader range of

362 forests is complicated by methodological limitations. For example, the classic canopy gap

363 definition we used includes some opennings that are small compared to the height of surrounding

364 trees, and may not meet recent recommendations for minimum size criteria (Zhu et al. 2015).

365 This underscores the merits of using approaches such as hemispheric photography for global

366 comparisons of canopy openness and light transmission. However, practical constraints dictate

367 that hemispheric photographs can only be used to sample a small proportion of a landscape. By

368 contrast, emerging applications of airborne laser scanning promise unprecedented capacity to

369 compare hemispheric measures of canopy openness over large areas and at multiple scales (e.g.,

370 Moeser et al. 2014). 
371 Origins of openness and sources of shade: processes leading to open and variable canopies

372 The origins of canopy openness - and sources of shade - differ between the two sites we studied, 373 reflecting differing processes of stand development and of developmental stages. Carmanah has

374 a bi-model distribution of light (Figure 4) likely associated with the higher density and irregular

375 spatial distribution of shade-casting conifers (Figure 5). At Kitlope there are few small and

376 intermediate sized conifers to create deep shade microsites (Figure 2). In terms of gap origins,

377 most gap microsites at Carmanah arise from the mortality of trees (Figure 3), and snags are

378 common in a range of size classes, as expected for an old-growth forest driven by gap-phase

379 processes. At Kitlope, by contrast, most gaps do not clearly have an associated gap-maker and

380 few large snags were observed. Many of the 'gaps' at Kitlope may be legacy openings that have

381 never been occupied by conifers. Very few of these legacy openings had obvious edaphic origins

382 (Figure 3). Potential causes of such low initial densities and persistent legacy openings include

383 frequent flooding and intense competition with shrubs/herbs, beginning early in stand

384 development (Van Pelt et al. 2006).

\section{Patterns of openness: spatial heterogeneity of understory light transmission}

386 Within these two stands, light levels vary substantially over short distances, producing complex

387 spatial patterns of light within each one-hectare site (Figure 5). Contour maps of light at the top

388 of the shrub layer provide a visual representation of the spatial rate of change in the abiotic

389 environment as a result of variable shading from trees. Our results show that light transmission

390 can both vary substantially over short distances (e.g., a change of $19 \%$ full sun over $14 \mathrm{~m}$ ) and

391 more gradually over longer distances (e.g., $<1 \%$ full sun over $20 \mathrm{~m}$ ), depending on location

392 within the stand. Such spatial variation in light has implications for fine-scale patterns of 
393 microclimate, animal habitat, and silvicultural opportunities, in addition to the vegetation

394 attributes examined in this study.

395 In many forests, the processes of mortality, recruitment and growth result in increasing levels of

396 structural and environmental heterogeneity over time (Franklin et al. 2002). We find that fine

397 scale mapping provides a compelling visual synthesis of the within-stand spatial heterogeneity of

398 canopy structure (canopy openness, canopy cover class, tree locations and sizes) and

399 environmental conditions (understory light) created by stand development and disturbance

400 (Figure 5). Despite differences in stand age and development history, both the Kitlope and

401 Carmanah stands have developed substantial spatial heterogeneity in the overstory and

402 understory. These spatial patterns are clearly related to gap-phase processes in the Carmanah

403 stand. At Kitlope, by contrast, there is little evidence of gap-phase dynamics suggesting other

404 processes must account for the observed spatial heterogeneity. Regardless of the explanation

405 (discussed further below), the younger Kitlope site provides an example of relatively rapid

406 development of a degree of old-growth character by floodplain forests (Van Pelt et al. 2006). Our

407 study, however, examined only a few of the characteristics that might differentiate old-growth

408 from younger (or managed) floodplain stands.

409 Understory response to openness: light transmission shapes understory vegetation

410 We observed fine-scale spatial variation of understory vegetation composition that is strongly

411 influenced by light transmission (or shading) by the overstory. At each site, the strongest

412 compositional gradient is correlated with light transmission, largely independent of edaphic

413 measures. However, the relationship between light and understory vegetation composition is

414 weaker at Carmanah, potentially due to a temporal lag in vegetation response to recent canopy

415 disturbance: the understory vegetation has not yet responded to the new resource distribution 
416 created by that disturbance. The influence of light could also be weaker at Carmanah because

417 more of the plant community is organized along a soil gradient. Here we observed that an

418 additional component of understory vegetation composition (Axis 2) was correlated with edaphic

419 conditions (soil organics and mineral texture). It is not surprising that there are more complex

420 interacting drivers of the understory plant community in the stand exhibiting both more complex

421 soils (e.g., a more developed forest floor; Table 2) and more recent canopy disturbance.

422 Species positively associated with light may have evolved strategies to exploit and dominate

423 higher light microsites. Ribes bracteosum and Rubus spectabilis, tall shrubs associated with light

424 in both our sites, are dominant in the understory of many open riparian areas across the CTR

425 (Pabst and Spies 1998, Sarr and Hibbs 2007b, Hocking and Reynolds 2011). The mechanisms of

426 R. spectabilis dominance have been well studied. This plant species utilizes rapid rhizome

427 extension and stem growth to colonize openings, overtop other plants, and maintain high

428 abundance (Tappeiner et al. 1991, Tappeiner et al. 2001). As a consequence, point level species

429 diversity in our study decreased with increasing cover of $R$. spectabilis. However, despite the

430 adaptations of $R$. spectabilis, our results suggest that its dominance of bright patches is not a

431 foregone conclusion in the presence of $R$. bracteosum and Sambucas racemosa.

432 While some species thrive in the brightest microsites, others reach greatest abundance in the

433 shade of overstory trees (e.g., Oplopanax horridus, Dryopteris expansa, Blechnum spicant, and

434 Osmorhiza berteroi). O. horridus increases abruptly in shadier microsites at Kitlope and is never

435 abundant above about 20\% light transmission - despite the fact that $O$. horridus can be observed

436 thriving in much brighter environments elsewhere (Burton 1998). At Carmanah, shadier

437 microsites also have higher evenness and lower dominance. In these open floodplain forests,

438 shady microsites may provide refuges from competition with dominant shrubs, such as Ribes 
439 bracteosum and Rubus spectabilis. These "shade refuges" contribute to greater community

440 diversity by allowing poorer light competitors to reach relative abundance somewhere in the

441 stand. We suggest that a shade refuge is an example of the broader phenomenon of spatial

442 refuges for diversity. Keppel et al. (2012) define refuges as "places that through structures or

443 processes provide shelter from disturbances, predation, herbivory or competition." Examples of

444 spatial refuges for plants include rock-outcrops functioning as refuges from herbivores (Chollet

445 et al. 2013) and hummocks functioning as refuges from invasive plant competitors in serpentine

446 grasslands (Gram et al. 2004).

447 Analysis of the Kitlope and Carmanah floodplain plots supports the assertion of Pabst and Spies

448 (1998) that overstory structure and light transmission are important drivers of understory

449 composition within riparian stands. In their study, overstory structural measures were correlated

450 with understory vegetation composition along streamside-to-hillslope topographic gradients and

451 were interpreted as proxies for light. Our results build on this idea by confirming that when

452 floodplains are examined independent of hillslope sites, light transmission is still correlated with

453 understory composition patterns at a fine scale within stands.

454 Despite the strong environmental correlates of understory composition, much variation in

455 understory composition remains unexplained. This is common for studies that examine

456 environment-composition relationships within forest understories (Frelich et al. 2003, Chávez

457 and Macdonald 2010). It is also not surprising that plant communities are not in equilibrium with

458 their (light) environments within dynamic, fluvially influenced stands. Other than the light,

459 edaphic, and vegetation properties we measured, processes that could play a role in structuring

460 floodplain plant communities at this spatial scale include chance colonization events, disturbance

461 (e.g., wind and tree-fall), the interaction of topography and flooding (Menges and Waller 1983, 
462 Little et al. 2013), ungulate herbivory (Woodward et al. 1994, Stockton et al. 2005), ground

463 water upwelling (Mouw et al. 2009), salmon derived nutrients (Hocking and Reynolds 2011),

464 overstory composition (Pabst and Spies 1998), and below-ground interaction with trees (e.g.,

465 Lindh et al. 2003).

Persistent patterns of openness: feedbacks on stand dynamics and canopy structure

467 The dominance of light-associated understory shrubs may also play a role in shaping the patterns

468 and dynamics of stand structure. At both Kitlope and Carmanah, shrubs are abundant, but

469 regenerating conifers are sparse - despite light transmission levels more than sufficient for

470 growth of at least some of the conifers present in the stand (Wright et al. 1998, Drever and

471 Lertzman 2001). Our observations are consistent with the "persistent gap" hypothesis, which - in

472 combination with canopy disturbance and perhaps flooding - could explain why Kitlope and

473 Carmanah both have very open canopies - and low tree densities - compared to many forests,

474 despite their different developmental stages. The phenomenon of understory plants influencing

475 gap-phase stand dynamics has been described for a wide range of forests (Royo and Carson

476 2006). At the scale of the CTR region, the importance of persistent shrub gaps might vary with

477 the intensity of herbivory, as high densities of ungulates have dramatically altered understory

478 vegetation at some locations (e.g., Woodward et al. 1994, Stockton et al. 2005).

479 Typical gap-phase processes are said to promote a spatially and temporally "moving window of

480 light availability" (Nicotra et al. 1999). Our results suggest an alternative process: hyper-

481 competitive shrubs can exclude conifer establishment and hold that window open and stationary

482 for some period of time. By invading and dominating openings, shrubs could increase the

483 persistence of the spatial patterns of openness created by canopy tree mortality - or by patterns

484 of initial site colonization. However, observations of conifer regeneration on logs (e.g., Harmon 
485 and Franklin 1989) suggest that the presence of logs in such settings could facilitate eventual 486 recruitment of canopy trees even in the presence of intense competition from a productive, 487 dominant shrub understory.

488 Conclusions

489 Convergent patterns of openness and overstory-understory interactions

490 Our analyses at Kitlope and Carmanah, suggest concepts of stand development and within-stand 491 interactions that may have broader applicability to coastal temperate rainforests. Across a range 492 of ages and developmental processes, these forests can attain very open canopies, resulting in 493 abundant understory light and vegetation development. Horizontal and vertical variation in forest 494 canopy structure results in complex spatial patterns of light and shade in the understory. The 495 resulting gradients of understory light in turn structure the understory community at fine scales, 496 with potential feedbacks on patterns of tree recruitment and overall stand density. This suggests 497 that different developmental processes and time-scales can result in stands of similar structure, 498 with open canopies, productive and diverse understories, and coupling of overstory and 499 understory plant layers. This conclusion has interesting implications for management practices 500 intended to restore or accelerate the presence of old forest characteristics in younger or managed 501 stands, particularly on floodplains. It is important to note in a management context, that it is as 502 much the variability in openness as openness itself that is an attribute of such older stands 503 (Frazer et al. 2000b).

504 In our data, open canopies allowed vigorous growth of dominant shrubs while tree canopies 505 created "shade refuges" where less competitive understory species persisted. The mix of both 506 bright and dark locations was an important factor underlying the distribution of diversity within 
507 the stands. Our results suggest that in the many high-density second-growth conifer forests on

508 similar sites, stand management that encourages canopy openness and heterogeneity (e.g.,

509 spatially variable thinning) may accelerate the development of processes and patterns seen at

510 Kitlope and Carmanah. This supports a model of functional openness in stands that reflects

511 various interacting sources - stand developmental processes and small-scale disturbances,

512 edaphic variability, and persistent occupancy of sites by shrubs. Landscape scale analyses - such

513 as those possible with airborne laser scanning - have the potential to characterize canopy

514 openness and understory interactions more comprehensively across a broad range of forest

515 conditions and environmental settings.

\section{Acknowledgements}

517 Funding for this project was provided by an NSERC Canada Graduate Scholarship and the BC

518 Forest Investment Account - Forest Science Program. All data were collected as part of a larger

519 Coastal Old Growth Dynamics Project of the BC Forest Service. We extend our sincere

520 appreciation to the many people who helped make this research possible and more successful:

521 Dr. Gordon Frazer, Dr. Paul Alaback, Dr. Alton Harestad, Dr. Marie-Josée Fortin, Heather

522 (West) Klassen, Kaeli Stark, Dr. Alana Gerecke, Jane Pendray, Rachel Field, Leah Ballin, Sonya

523 Powell, Rachel White, Molly Hudson, Liz Poulsom, Jason Smith, Dr. Audrey Pearson, Dr.

524 Andrew Cooper, Audrey Roburn, Bill Beese, Dr. Akira Mori, the Haisla First Nation and

525 Kitamaat Village Council. We are grateful to the editors and three anonymous reviewers for

526 comments that greatly improved the manuscript. 


\section{References}

Bartemucci, P., D.K. Coates, K.A. Harper, and E.F. Wright. 2002. Gap disturbances in northern old-growth forests of British Columbia, Canada. J. Veg. Sci. 13: 685-696.

Bartemucci, P., C. Messier, and C.D. Canham. 2006. Overstory influences on light attenuation patterns and understory plant community diversity and composition in southern boreal forests of Quebec. Can. J. For. Res. 36: 2065-2079.

B.C. Conservation Data Centre. 2017. BC Species and Ecosystems Explorer. B.C. Minist. of Environ. Victoria, B.C. Available: http://a100.gov.bc.ca/pub/eswp/ (accessed Apr 5, 2017).

BC Ministry of Forests and BC Ministry of Environment Lands and Parks. 1998. Field manual for describing terrestrial ecosystems: Land Management Handbook Number 25. BC Ministry of Forests and BC Ministry of Environment Lands and Parks.

BC Ministry of Forests. 2001. Mensuration data from the provincial ecology program. For. Sci. Prog., B.C. Min. For., Victoria, B.C. Work. Pap. 62/2001. http://www.for.gov.bc.ca/hfd/pubs/Docs/Wp/Wp62.htm

Brokaw, N.V.L. 1985. Treefalls, regrowth, and community structure in tropical forests. In The ecology of natural disturbance and patch dynamics. Edited by Pickett, S.T.A., and P.S. White. Academic Press, Orlando, FL. pp. 53-69.

Burton, P.J. 1998. Inferring the response of berry-producing shrubs to partial cutting in the ICHmc. Unpublished final report to Forest Renewal BC Research Program. Symbios Research and Restoration, Smithers, BC.

Canham, C.D., J.S. Denslow, W.J. Platt, J.R. Runkle, T.A. Spies, and P.S. White. 1990. Light regimes beneath closed canopies and tree-fall gaps in temperate and tropical forests. Can. J. For. Res. 20: 620-631.

Chávez, V. and S.E. Macdonald. 2010. The influence of canopy patch mosaics on understory plant community composition in boreal mixedwood forest. For. Ecol. Manage. 259: 1067-1075.

Chollet, S., C. Baltzinger, L. Ostermann, F. Saint-André, and J-L. Martin. 2013. Importance for forest plant communities of refuges protecting from deer browsing. For. Ecol. Manage. 289: $470-477$.

Denslow, J.S. 1985. Disturbance-mediated coexistence of species. In The ecology of natural disturbance and patch dynamics. Edited by Pickett, S.T.A., and P.S. White. Academic Press, Orlando, FL. pp. 307-323.

Drever, R.C. and K.P. Lertzman. 2001. Light-growth response of coastal Douglas-fir and western redcedar saplings under different regimes of soil moisture and nutrients. Can. J. For. Res. 31: 2124-2133. 
Dutilleul, P. 1993. Modifying the $t$ test for assessing the correlation between two spatial processes. Biometrics, 49: 305-314.

Franklin, J.F., T.A. Spies, R. Van Pelt, A.B. Carey, D.A. Thornburgh, D.R. Berg, D.B. Lindenmayer, M.E. Harmon, W.S. Keeton, D.C. Shaw, K. Bible, and J. Chen. 2002. Disturbances and structural development of natural forest ecosystems with silvicultural implications, using Douglas-fir forests as an example. For. Ecol. Manage. 155: 399-423.

Frazer, G.W., C.D. Canham, and K.P. Lertzman. 1999. Gap Light Analyzer (GLA) Version 2.0: Imaging software to extract forest canopy structure and gap light transmission indices from true-colour hemispherical (fisheye) photographs. Simon Fraser University, Burnaby, British Columbia, and the Institute of Ecosystem Studies, Millbrook, New York.

Frazer, G.W., C.D. Canham, and K.P. Lertzman. 2000a. Gap Light Analyzer Version 2.0. Bull. Ecol. Soc. Amer. 81: 191-197.

Frazer, G.W., J.A. Trofymow, and K.P. Lertzman. 2000b. Canopy openness and leaf area in chronosequences of coastal temperate rainforests. Can. J. For. Res. 30: 239-256.

Frelich, L.E., J. Machado, and P.B. Reich. 2003. Fine-scale environmental variation and structure of understory plant communities in two old-growth pine forests. J. Ecol. 91: 283-293.

Giesbrecht, I.J.W. 2010. Understory light and vegetation in two floodplain forests in coastal British Columbia. MRM research project, Simon Fraser University, Burnaby, BC. Report No. 508.

Gram, W.K., E.T. Borer, K.L. Cottingham, E.W. Seabloom, V.L. Boucher, L. Goldwasser, F. Micheli, B.E. Kendall, and R.S. Burton. 2004. Distribution of plants in a California serpentine grassland: are rocky hummocks spatial refuges for native species? Plant Ecol. 172: $159-171$.

Green, R.N. and K. Klinka. 1994. A field guide to site identification and interpretation for the Vancouver Forest Region. British Columbia Ministry of Forests, Research Branch.

Gregory, S.V., F.J. Swanson, W.A. McKee, and K.W. Cummins. 1991. An ecosystem perspective of riparian zones. BioScience, 41: 540-551.

Gurevitch, J., S.M. Scheiner, and G.A. Fox. 2002. The ecology of plants. Sinauer Associates, Inc., Sunderland, MA.

Harmon, M.E. and J.F. Franklin. 1989. Tree seedlings on logs in Picea-Tsuga forests of Oregon and Washington. Ecology, 70: 48-59.

Henderson, J.A. 1978. Plant succession on the Alnus rubra/Rubus spectabilis habitat type in western Oregon. Northwest Sci. 52: 156-167.

Hocking, M.D. and J.D. Reynolds. 2011. Impacts of salmon on riparian plant diversity. Science, 331: 1609-1612. 
Keppel, G. and G.W. Wardell-Johnson. 2012. Refugia: keys to climate change management. Global Change Biol. 18: 2389-2391.

Kruskal, J.B. 1964. Nonmetric multidimensional scaling: a numerical method. Psychometrika, 29: 115-129.

Legendre, P. and L. Legendre. 1998. Numerical ecology. $2^{\text {nd }}$ edition. Elsevier, Amsterdam.

Lertzman, K.P. and C.J. Krebs. 1991. Gap-phase structure of a subalpine, old-growth forest. Can. J. For. Res. 21: 1730-1741.

Lertzman, K.P., G.D. Sutherland, A. Inselberg, and S.C. Saunders. 1996. Canopy gaps and the landscape mosaic in a coastal temperate rain forest. Ecology, 77: 1254-1270.

Levey, D.J. 1988. Tropical wet forest treefall gaps and distributions of understory birds and plants. Ecology, 69: 1076-1089.

Lieberman, M., D. Lieberman, and R. Peralta. 1989. Forests are not just Swiss cheese: canopy stereogeometry of non-gaps in tropical forests. Ecology, 70: 550-555.

Lindh, B.C., A.N. Gray, and T.A. Spies. 2003. Responses of herbs and shrubs to reduced root competition under canopies and in gaps: a trenching experiment in old-growth Douglasfir forests. Can. J. For. Res. 33: 2052-2057.

Little, P.J., J.S. Richardson, and Y. Alila. 2013. Channel and landscape dynamics in the alluvial forest mosaic of the Carmanah River valley, British Columbia, Canada. Geomorphology, 202: $86-100$.

MacKinnon, A., S.C. Saunders, and H. Klassen. 2010. Coast forest region old growth dynamics (OGD) project [online]. Available from www.for.gov.bc.ca/rco/research/eco/oldgrowthforests/oldgrowthdynamics/index.htm [accessed 1 Dec 2010].

Mather, P.M. 1976. Computational methods of multivariate analysis in physical geography. J. Wiley \& Sons, London. 532pp.

McCarthy, J. 2000. Gap dynamics of forest trees: a review with particular attention to boreal forests. Envir. Rev. 9: 1-59.

McCune, B. and J.B. Grace. 2002. Analysis of ecological communities. MjM Software Design, Gleneden Beach, Oregon.

McCune, B. and M.J. Mefford. 2006. PC-ORD. Multivariate Analysis of Ecological Data. Version 5.19. MjM Software, Gleneden Beach, Oregon, U.S.A.

McGhee, R.A. 1996. Ecology and management of hardwoods in coniferous forests: a case study of vine maple persistence. MRM research project, Simon Fraser University, Burnaby, BC. Report No 189.

Meidinger, D. and J. Pojar. 1991. Ecosystem of British Columbia. Province of British Columbia, Ministry of Forests, Research Branch, Victoria. 
Meidinger, D., T. Lee, G. Douglas, W. George, G. Britton, W. MacKenzie, and H. Qian. 2009. British Columbia plant species codes and selected attributes. Version 6 Database. Research Branch. B.C. Ministry of Forests.

Menges, E.S. and D.M. Waller. 1983. Plant strategies in relation to elevation and light in floodplain herbs. Amer. Nat. 122: 454-473.

Minore, D. and H.G. Weatherly. 1994. Riparian trees, shrubs, and forest regeneration in the coastal mountains of Oregon. New For. 8: 249-263.

Mladenoff, D. 1990. The relationship of the soil seed bank and understory vegetation in oldgrowth northern hardwood-hemlock treefall gaps. Can. J. Bot. 68: 2714-2721.

Moeser, D., J. Roubinek, P. Schleppi, F. Morsdorf, and T. Jonas. 2014. Canopy closure, LAI and radiation transfer from airborne LiDAR synthetic images. Agric. For. Meteorol. 197: $158-168$.

Mouw, J.E.B., J.A. Standford, and P.B. Alaback. 2009. Influences of flooding and hyporheic exchange on floodplain plant richness and productivity. Riv. Res. Appl. 25: 929-945.

Naiman, R.J., J.S. Bechtold, T.J. Beechie, J.J. Latterell, and R. Van Pelt. 2010. A process-based view of floodplain forest patterns in coastal river valleys of the Pacific Northwest. Ecosystems, 13: 1-31.

Nicotra, A.B., R.L. Chazdon, and S.V.B. Iriarte. 1999. Spatial heterogeneity of light and woody seedling regeneration in tropical wet forests. Ecology, 80: 1908-1926.

Pabst, R.J. and T.A. Spies. 1998. Distribution of herbs and shrubs in relation to landform and canopy cover in riparian forests in coastal Oregon. Can. J. Bot. 76: 298-315.

Pabst, R.J. and T.A. Spies. 1999. Structure and composition of unmanaged riparian forests in the coastal mountains of Oregon, U.S.A. Can. J. For. Res. 29: 1557-1573.

Pearson, A.F. 2010. Natural and logging disturbances in the temperate rain forests of the Central Coast, British Columbia. Can. J. For. Res. 40: 1970-1984.

Pielou, E.C. 1969. An introduction to mathematical ecology. John Wiley and Sons, New York.

Rosenberg, M.S. 2009. PASSaGE 2: Pattern Analysis, Spatial Statistics and Geographic Exegesis. Software available online: http://www.passagesoftware.net/index.php

Royo, A.A. and W.P. Carson. 2006. On the formation of dense understory layers in forests worldwide: consequences and implications for forest dynamics, biodiversity, and succession. Can. J. For. Res. 36: 1345-1362.

Runkle, J.R. 1984. Development of woody vegetation in treefall gaps in a beech-sugar maple forest. Holarct. Ecol. 7: 157-164.

Sarr, D.A. and D.E. Hibbs. 2007a. Multiscale controls on woody plant diversity in western Oregon riparian forests. Ecol. Mono. 77: 179-201. 
Sarr, D.A. and D.E. Hibbs. 2007b. Woody riparian plant distributions in western Oregon, USA: comparing landscape and local scale factors. Plant Ecol. 190: 291-311.

Saxton, K.E. and W.J. Rawls. 2006. Soil water characteristic estimate by texture and organic matter for hydrologic solutions. Soil Sci. Am. J. 70: 1569-1578.

Schoonmaker, P.K., B. von Hagen, and E.C. Wolf. 1997. Introduction. In The rainforests of home: profile of a North American bioregion. Edited by P.K. Schoonmaker, B. von Hagen, and E.C. Wolf. Island Press, Washington, DC. pp. 1-6.

Schliemann, S.A. and J.C. Bockheim. 2011. Methods for studying treefall gaps: a review. For. Ecol. Manage. 261: 1143-1151.

Soil Classification Working Group. 1998. The Canadian System of Soil Classification (third edition). Agriculture and Agri-Food Canada Publication 1646, pp. 187.

Spies, T.A. and J.F. Franklin. 1988. Old growth and forest dynamics in the Douglas-fir region of Western Oregon and Washington. Nat. A. J. 8: 190-201.

Spies, T.A. and J.F. Franklin. 1989. Gap characteristics and vegetation response in coniferous forests of the Pacific Northwest. Ecology, 70: 543-545.

Stockton, S.A., S. Allombert, A.J. Gaston, and J.-L. Martin. 2005. A natural experiment on the effects of high deer densities on the native flora of coastal temperate rain forests. Biol. Cons. 126: 118-128.

Tappeiner, J., J. Zasada, P. Ryan, and M. Newton. 1991. Salmonberry clonal and population structure: the basis for a persistent cover. Ecology, 72: 609-618.

Tappeiner, J.C. II, J.C. Zasada, D.W. Huffman, and L.M. Ganio. 2001. Salmonberry and salal annual aerial stem production: the maintenance of shrub cover in forest stands. Can. J. For. Res. 31: 1629-1638.

Turner, N.J. 1998. Plant technology of First Peoples in British Columbia. Royal British Columbia Museum Handbook. UBC Press, Vancouver.

Van Pelt, R. and J.F. Franklin. 2000. Influence of canopy structure on the understory environment in tall, old-growth, conifer forests. Can. J. For. Res. 30: 1231-1245.

Van Pelt, R., T.C. O’Keefe, J.J. Latterell, and R.J. Naiman. 2006. Riparian forest stand development along the Queets River in Olympic National Park, Washington. Ecol. Mono. 76: 227-298.

Watt, A.S. 1947. Pattern and process in the plant community. J. Ecol. 35: 1-22.

Wells, R., K.P. Lertzman, and S.C. Saunders. 1998. Old-growth definitions for the forests of British Columbia, Canada. Nat. Areas J. 18: 279-292.

Woodward, A., E.G. Schreiner, D.B. Houston, and B.B. Moorhead. 1994. Ungulate-forest relationships in Olympic National Park: retrospective exclosure studies. Northwest Sci. 68: $97-110$. 
Wright, E.F., K.D. Coates, C.D. Canham, and P. Bartemucci. 1998. Species variability in growth response to light across climatic regions in northwestern British Columbia. Can. J. For. Res. 28: 871-886.

Zhu, J., G. Zhang, G.G. Wang, Q. Yan, D. Lu, X. Li, and X. Zheng. 2015. On the size of forest gaps: Can their lower and upper limits be objectively defined? Agric. For. Meteorol. 213: 64-76. 


\section{Tables and Figures}

\section{Tables}

Table 1. Geographic and growing season characteristics for Kitlope and Carmanah.

\begin{tabular}{lll}
\hline & Kitlope & Carmanah \\
\hline Location & & \\
Latitude (N) & $53^{\circ} 12^{\prime} 10.0^{\prime \prime}$ & $48^{\circ} 40^{\prime} 07.6^{\prime \prime}$ \\
Longitude (W) & $127^{\circ} 49^{\prime} 35.9^{\prime \prime}$ & $124^{\circ} 41^{\prime} 10.8^{\prime \prime}$ \\
Elevation (m) & 8 & 138 \\
Growing season start and end & & \\
DD5-100 (date of budburst for most plants) & May 9 & April 5 \\
bFFP: (beginning of the frost free period) & May 18 & April 11 \\
eFFP: (end of the frost free period) & Oct 3 & Nov 2 \\
Inferred start of growing season & May 9 & April 5 \\
Inferred end of growing season & Sept 12 & Oct 12 \\
\hline
\end{tabular}


Table 2. Descriptive statistics for environment variables at each site. Organic and mineral horizon descriptors (LFH, Ah) follow the Canadian System of Soil Classification (Soil Classification Working Group 1998).

\begin{tabular}{|c|c|c|c|c|c|c|c|c|c|c|}
\hline \multirow{3}{*}{$\frac{\text { Variable }}{\text { Substrate and Forest Floor }}$} & \multicolumn{5}{|c|}{ Kitlope } & \multicolumn{5}{|c|}{ Carmanah } \\
\hline & \multicolumn{2}{|c|}{$n$ Median } & \multirow[t]{2}{*}{ Mean } & \multicolumn{2}{|c|}{ SD CV (\%) } & \multicolumn{2}{|c|}{$n$ Median } & \multirow[t]{2}{*}{ Mean } & \multicolumn{2}{|c|}{ SD CV (\%) } \\
\hline & & & & & & & & & & \\
\hline Forest Floor (\% cover) & 24 & 3 & 6 & 14 & 223 & 16 & 85 & 81 & 21 & 26 \\
\hline CWD $(\%$ cover $)$ & 24 & 0 & 5 & 9 & 193 & 16 & 15 & 18 & 21 & 115 \\
\hline Mineral Soil ( $\%$ cover) & 24 & 96 & 87 & 22 & 25 & 16 & 0 & 1 & 2 & 400 \\
\hline Humus thickness (cm) & 24 & 0.0 & 0.0 & 0.0 & 490 & 16 & 2.5 & 2.6 & 1.7 & 66 \\
\hline LFH thickness $(\mathrm{cm})$ & 24 & 0.5 & 0.6 & 0.5 & 89 & 16 & 3.5 & 4.0 & 2.3 & 58 \\
\hline Ah thickness $(\mathrm{cm})$ & 24 & 4.1 & 4.9 & 2.7 & 55 & 16 & 1.3 & 1.5 & 1.2 & 80 \\
\hline Dead Wood in LFH (\% vol.) & 24 & 0 & 1 & 3 & 237 & 16 & 0 & 6 & 12 & 193 \\
\hline \multicolumn{11}{|c|}{ Soil Texture and Water Properties } \\
\hline$\%$ Clay & 24 & 20 & 21 & 11 & 53 & 16 & 10 & 11 & 8 & 72 \\
\hline$\%$ Silt & 24 & 56 & 53 & 20 & 37 & 16 & 25 & 32 & 28 & 88 \\
\hline$\%$ Sand & 24 & 20 & 26 & 23 & 89 & 16 & 65 & 58 & 31 & 54 \\
\hline$\%$ Coarse Fragments & 24 & 0 & 0 & 0 & na & 16 & 3 & 26 & 34 & 133 \\
\hline $\begin{array}{l}\text { Plant Available Water }\left(\mathrm{cm}^{3}\right. \\
\left.\text { water } / \mathrm{cm}^{3} \text { soil }\right)\end{array}$ & 24 & 17 & 17 & 5 & 29 & 16 & 8 & 10 & 8 & 77 \\
\hline $\begin{array}{l}\text { Hydraulic conductivity } \\
(\mathrm{cm} / \mathrm{hr})\end{array}$ & 24 & 12 & 21 & 22 & 106 & 16 & 33 & 38 & 26 & 68 \\
\hline \multicolumn{11}{|c|}{$\begin{array}{l}\text { Overstory Structure and Light Transmission } \\
\text { Omitting terrace and fluvial channel microsites }\end{array}$} \\
\hline$\%$ Site openness & 49 & 11.6 & 11.5 & 2.6 & 22.9 & 39 & 11.0 & 11.1 & 3.3 & 30.1 \\
\hline LAI 4 (Leaf Area Index 4) & 49 & 2.5 & 2.5 & 0.2 & 9.6 & 39 & 2.5 & 2.5 & 0.4 & 15.4 \\
\hline LAI 5 (Leaf Area Index 5) & 49 & 2.5 & 2.5 & 0.2 & 8.9 & 39 & 2.7 & 2.7 & 0.3 & 11.5 \\
\hline Direct PAR $\left(\mathrm{mol} / \mathrm{m}^{2} / \mathrm{d}\right)$ & 49 & 0.6 & 0.7 & 0.3 & 46.1 & 39 & 0.6 & 0.6 & 0.3 & 40.6 \\
\hline Diffuse PAR ( $\left.\mathrm{mol} / \mathrm{m}^{2} / \mathrm{d}\right)$ & 49 & 3.8 & 3.8 & 1.0 & 26.1 & 39 & 3.5 & 3.4 & 1.1 & 32.1 \\
\hline Total PAR (mol/m²/d) & 49 & 4.3 & 4.5 & 1.1 & 25.4 & 39 & 4.1 & 4.1 & 1.3 & 31.9 \\
\hline$\%$ Direct PAR & 49 & 14.8 & 17.2 & 8.0 & 46.2 & 39 & 17.6 & 17.6 & 7.1 & 40.5 \\
\hline$\%$ Diffuse PAR & 49 & 18.7 & 19.1 & 5.0 & 26.1 & 39 & 18.0 & 17.9 & 5.8 & 32.1 \\
\hline$\%$ PAR (aka. \% full sun) & 49 & 17.7 & 18.8 & 4.8 & 25.3 & 39 & 17.9 & 17.9 & 5.7 & 31.9 \\
\hline
\end{tabular}

CWD is coarse woody debris; LFH is the sum of all soil organic horizons; Ah is an organic rich mineral soil layer; and PAR is photosynthetically active radiation. 
Table 3. Summary statistics for ordination results at Kitlope $(n=24)$. The cumulative proportion of variation represented by the three axes $\left(R^{2}\right)$ is 0.79 before and after rotation. Bold font identifies correlations with $r^{2} \geq 0.3$. Species names follow Meidinger et al. (2009).

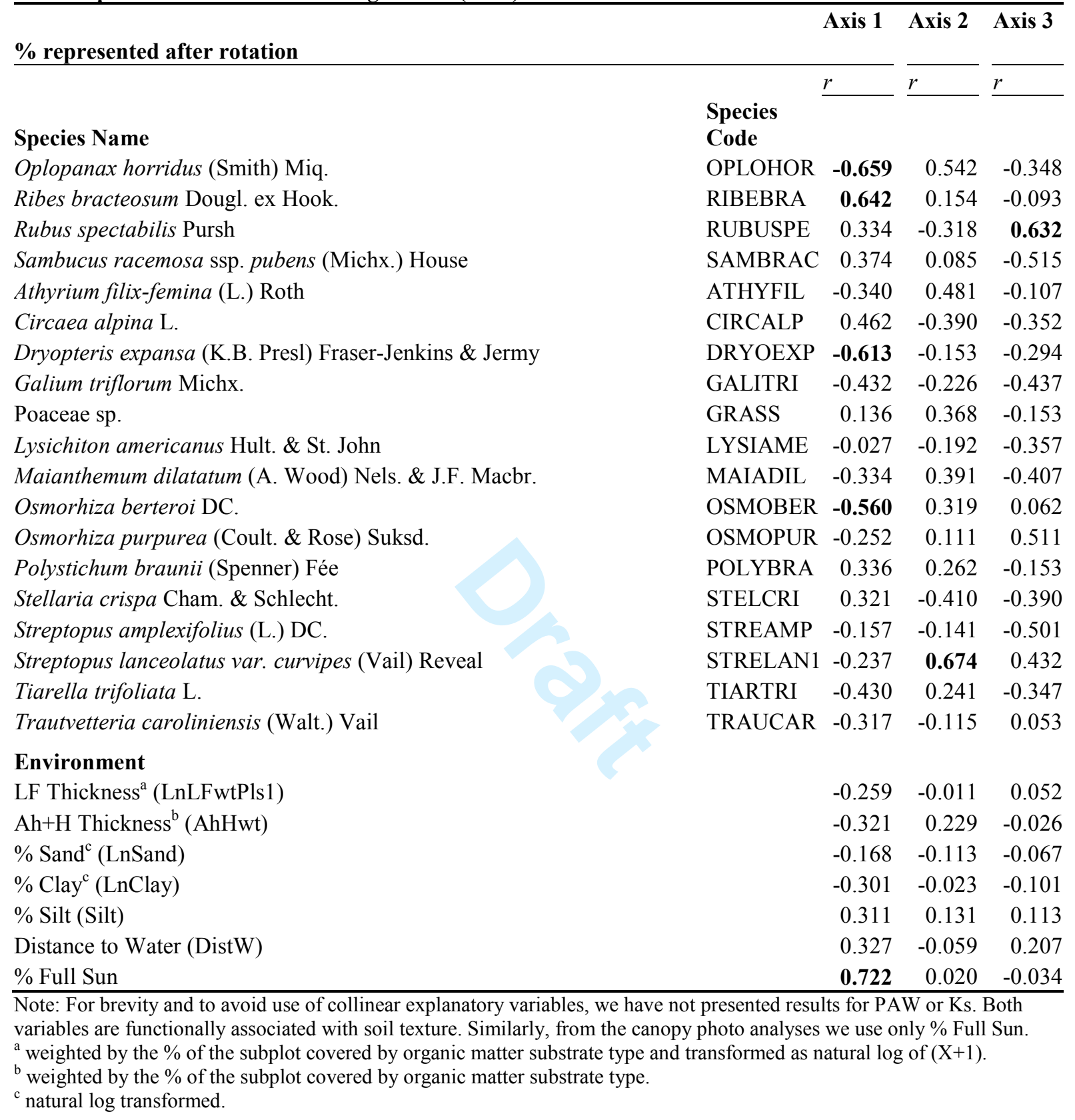


Table 4. Summary statistics for ordination results at Carmanah $(n=16)$. The cumulative proportion of variation represented by the three axes $\left(R^{2}\right)$ is 0.90 before and after rotation. Bold font identifies correlations with $r^{2} \geq 0.3$.

\begin{tabular}{|c|c|c|c|c|}
\hline \multirow{2}{*}{$\%$ represented after rotation } & & Axis 1 & \multirow{3}{*}{$\begin{array}{l}\text { Axis } 2 \\
r\end{array}$} & \multirow{3}{*}{$\begin{array}{l}\text { Axis } 3 \\
r \\
\end{array}$} \\
\hline & & & & \\
\hline & & $\underline{r}$ & & \\
\hline Species Name & $\begin{array}{l}\text { Species } \\
\text { Code }\end{array}$ & & & \\
\hline Ribes bracteosum & RIBEBRA & 0.669 & 0.061 & 0.216 \\
\hline Rubus spectabilis & RUBUSPE & 0.730 & 0.109 & 0.009 \\
\hline Vaccinium parvifolium $\mathrm{Sm}$. & VACCPAR & -0.514 & 0.393 & 0.149 \\
\hline Athyrium filix-femina & ATHYFIL & -0.246 & 0.349 & 0.462 \\
\hline Blechnum spicant (L.) Roth & BLECSPI & -0.656 & 0.736 & 0.194 \\
\hline Boykinia occidentalis T. \& G. & BOYKELA & -0.273 & -0.174 & 0.687 \\
\hline Claytonia sibirica $\mathrm{L}$ & CLAYSIB & -0.043 & -0.541 & 0.712 \\
\hline Prosartes smithii (Hook.) Utech, Shinwari \& Kawano & DISPSMI & -0.364 & -0.571 & -0.121 \\
\hline Dryopteris expansa & DRYOEXP & -0.257 & 0.743 & -0.164 \\
\hline Galium triflorum & GALITRF & -0.290 & -0.203 & 0.743 \\
\hline Maianthemum dilatatum & MAIADIL & -0.506 & 0.354 & 0.213 \\
\hline Mitella ovalis Greene & MITEOVA & -0.282 & -0.095 & 0.733 \\
\hline Polystichum munitum (Kaulf.) K.B. Presl & POLYMUN & -0.370 & -0.385 & -0.295 \\
\hline Tiarella trifoliata & TIARTRI & 0.092 & -0.194 & 0.549 \\
\hline Trautvetteria caroliniensis & TRAUCAR & 0.192 & -0.211 & 0.183 \\
\hline \multicolumn{5}{|l|}{ Environment } \\
\hline Forest Floor Thickness (FF) & & 0.002 & -0.507 & 0.138 \\
\hline LF Thickness $^{\mathrm{a}}$ (LnLFwtPls1) & & 0.292 & -0.343 & -0.280 \\
\hline H Thickness $^{\mathrm{b}}$ (Hwt) & & -0.205 & -0.559 & 0.143 \\
\hline $\mathrm{Ah}+\mathrm{H}$ Thickness ${ }^{\mathrm{b}}(\mathrm{AhHwt})$ & & -0.034 & -0.523 & -0.013 \\
\hline$\%$ Sand (Sand) & & 0.341 & -0.244 & 0.089 \\
\hline$\%$ Clay $^{\mathrm{c}}$ (LnClay) & & -0.242 & 0.673 & -0.009 \\
\hline$\%$ Silt (Silt) & & -0.345 & 0.111 & -0.115 \\
\hline$\%$ Full Sun & & 0.571 & -0.014 & -0.001 \\
\hline
\end{tabular}


Table 5. Correlation analysis of: a. understory vegetation layers in relation to light; $b$. total herb cover in relation to the shrub layer; c. diversity in relation to light; d. diversity in relation to Rubus spectabilis cover. Bold coefficients are significant at the 0.05 level according to Dutilleul corrected $P$ values.

\begin{tabular}{|c|c|c|c|c|c|c|c|c|c|c|c|c|c|}
\hline \multirow[b]{3}{*}{ Variable 1} & \multirow[b]{3}{*}{ Variable 2} & \multicolumn{4}{|c|}{ Kitlope } & \multicolumn{4}{|c|}{ Carmanah (all) } & \multicolumn{4}{|c|}{ Carmanah (no windthrow) } \\
\hline & & \multicolumn{4}{|c|}{$n=24$} & \multicolumn{4}{|c|}{$n=19^{\mathrm{a}}$} & \multicolumn{4}{|c|}{$n=16^{\mathrm{a}}$} \\
\hline & & $r$ & $P$ & $P_{\text {Dut }}$ & $n_{e} \mathrm{GL}$ & $r$ & $P$ & $P_{\text {Dut }}$ & $n_{e} \mathrm{GL}$ & $r$ & $P$ & $P_{\text {Dut }}$ & $n_{e} \mathrm{GL}$ \\
\hline \multicolumn{14}{|c|}{ a. Layer vs. Light } \\
\hline Shrub & $\%$ Full Sun & 0.48 & 0.017 & 0.023 & 22 & 0.34 & 0.161 & 0.155 & 19 & 0.63 & 0.008 & 0.008 & 16 \\
\hline Herb & $\%$ Full Sun & -0.33 & 0.110 & 0.112 & 24 & -0.05 & 0.849 & 0.886 & 12 & -0.01 & 0.957 & 0.959 & 15 \\
\hline Vascular & $\%$ Full Sun & 0.29 & 0.167 & 0.167 & 24 & 0.30 & 0.214 & 0.139 & 26 & 0.59 & 0.017 & 0.029 & 14 \\
\hline sRUBUSPE & $\%$ Full Sun & 0.24 & 0.260 & 0.248 & 25 & 0.45 & 0.052 & 0.052 & 19 & 0.79 & 0.000 & 0.001 & 13 \\
\hline \multicolumn{14}{|c|}{ b. Herb Layer vs. Shrubs } \\
\hline Herb & Shrub & -0.12 & 0.587 & 0.574 & 26 & -0.24 & 0.314 & 0.336 & 18 & -0.22 & 0.422 & 0.482 & 13 \\
\hline Herb & sRUBUSPE & -0.41 & 0.044 & 0.040 & 25 & -0.08 & 0.730 & 0.705 & 22 & -0.01 & 0.964 & 0.965 & 15 \\
\hline \multicolumn{14}{|c|}{ c. Diversity vs. Light } \\
\hline S & $\%$ Full Sun & -0.22 & 0.292 & 0.336 & 20 & -0.43 & 0.067 & 0.138 & 13 & -0.47 & 0.065 & 0.077 & 15 \\
\hline E & $\%$ Full Sun & -0.09 & 0.668 & 0.640 & 28 & -0.53 & 0.021 & 0.063 & 13 & -0.64 & 0.008 & 0.010 & 15 \\
\hline $\mathrm{Ls}^{\mathrm{b}}$ & $\%$ Full Sun & 0.13 & 0.537 & 0.511 & 27 & 0.63 & 0.004 & 0.032 & 12 & 0.72 & 0.002 & 0.004 & 14 \\
\hline \multicolumn{14}{|c|}{ d. Diversity vs. Rubus spectabilis } \\
\hline S & sRUBUSPE & -0.16 & 0.456 & 0.436 & 26 & -0.31 & 0.196 & 0.137 & 24 & -0.43 & 0.095 & 0.091 & 16 \\
\hline E & sRUBUSPE & -0.67 & 0.000 & 0.001 & 23 & -0.67 & 0.002 & 0.002 & 18 & -0.65 & 0.006 & 0.008 & 15 \\
\hline $\mathrm{Ls}^{\mathrm{b}}$ & sRUBUSPE & 0.71 & 0.000 & 0.000 & 23 & $\mathbf{0 . 7 0}$ & 0.001 & 0.000 & 21 & 0.73 & 0.001 & 0.002 & 15 \\
\hline \multicolumn{14}{|c|}{$r$ : Pearson correlation coefficient. This estimate is not adjusted by the Dutilleul procedure. } \\
\hline \multicolumn{14}{|c|}{$\begin{array}{l}n_{e}: \text { effective sample size, after Dutilleul correction. } \\
P: \text { the } P \text {-value from a conventional } \mathrm{t} \text {-test, not corrected for spatial autocorrelation. }\end{array}$} \\
\hline \multicolumn{14}{|c|}{$P_{D u t}:$ the $P$-value from a Dutilleul corrected t-test, which accounts for spatial autocorrelation of each variable. } \\
\hline $\begin{array}{l}\text { GL: Gain “+ } \\
\text { sRUBUSPE: } \\
\text { S: species ric } \\
\text { E: species ev } \\
\text { Ls: species d } \\
\text { a correlations } \\
b^{2}\end{array}$ & $\begin{array}{l}\text { 'or Loss “-” of } \\
\text { summed cover } \\
\text { hness. } \\
\text { enness. } \\
\text { ominance. }\end{array}$ & $\begin{array}{l}\text { statisti } \\
\text { of } R u b\end{array}$ & $\begin{array}{l}\text { cal sign } \\
\text { us spec }\end{array}$ & $\begin{array}{l}\text { ificanc } \\
\text { tabilis }\end{array}$ & $\begin{array}{l}\text { e at the } \\
\text { in all las }\end{array}$ & $\begin{array}{l}0.0516 \\
\text { yers. }\end{array}$ & vel) afte & ter apply & ying the & Dutille & eul corre & rection. & \\
\hline
\end{tabular}




\section{Figures}

Figure 1. Map of Kitlope and Carmanah study locations in coastal British Columbia, Canada.

Figure 2. Diameter (DBH) distributions of live trees within the Kitlope and Carmanah plots. Colours are used to differentiate species.

Figure 3. Frequency of three canopy cover types at each site. Closed canopy (CC), expanded gap (EG), and canopy gap (CG). Figures are based on $n=42$ at Carmanah, after omitting terrace microsites, and $n=50$ at Kitlope.

Figure 4. Frequency distribution of $\%$ full sun. Fluvial channel and terrace microsites were omitted: $n=49$ at Kitlope, $n=39$ at Carmanah.

Figure 5. Maps of understory light (\% full sun) in relation to overstory tree size and location. Light values between sample locations were estimated and mapped using a tension spline interpolation.

Figure 6. NMS ordination diagrams and joint-plots for the two primary axes at Kitlope $(n=24)$ and Carmanah $(n=16)$. The angle of the arrow represents the direction of correlation between ordination scores and light transmission. The length of the arrow represents correlation strength. Only correlations with $r^{2}>0.3$ are shown. 


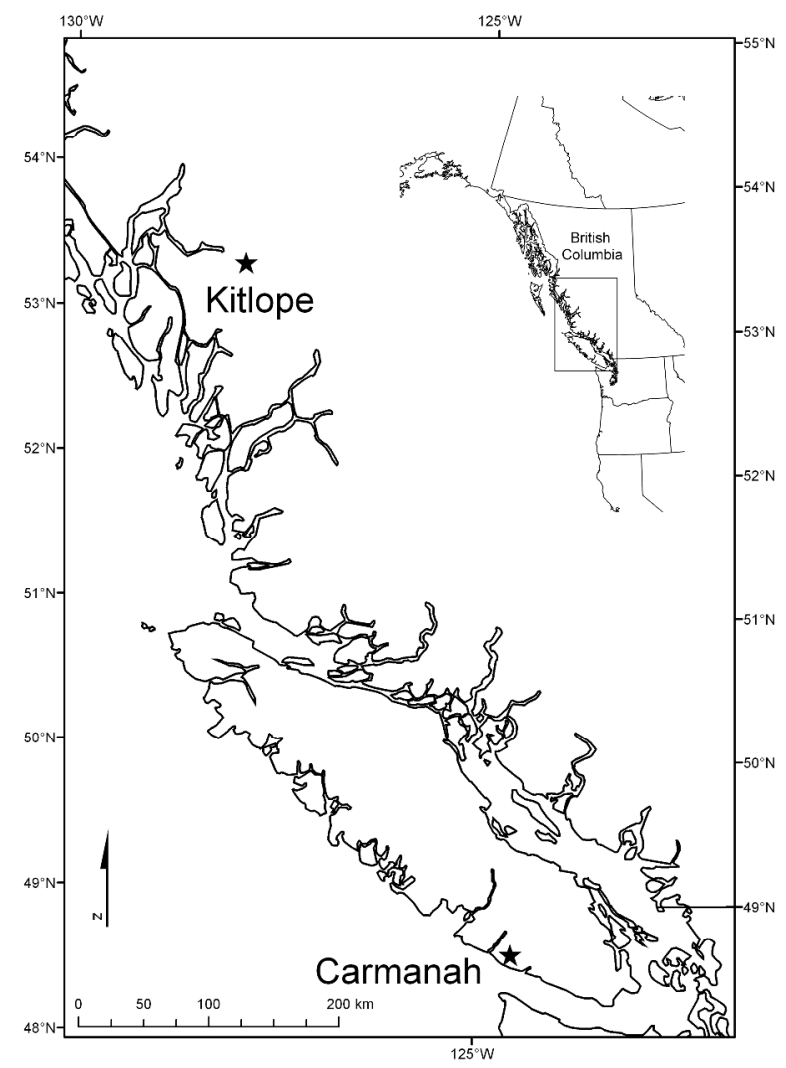

Figure 1. 


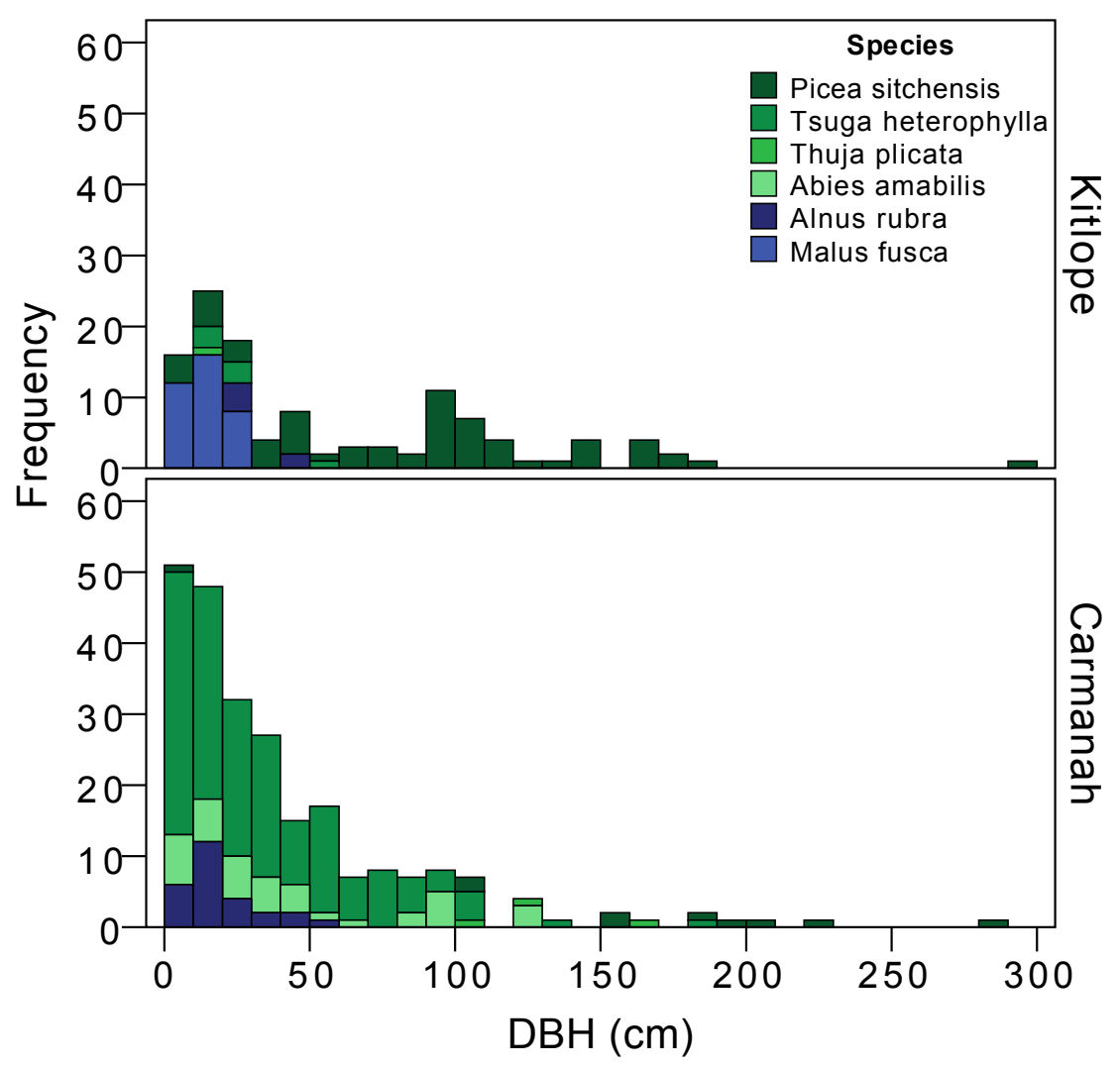

Figure 2 


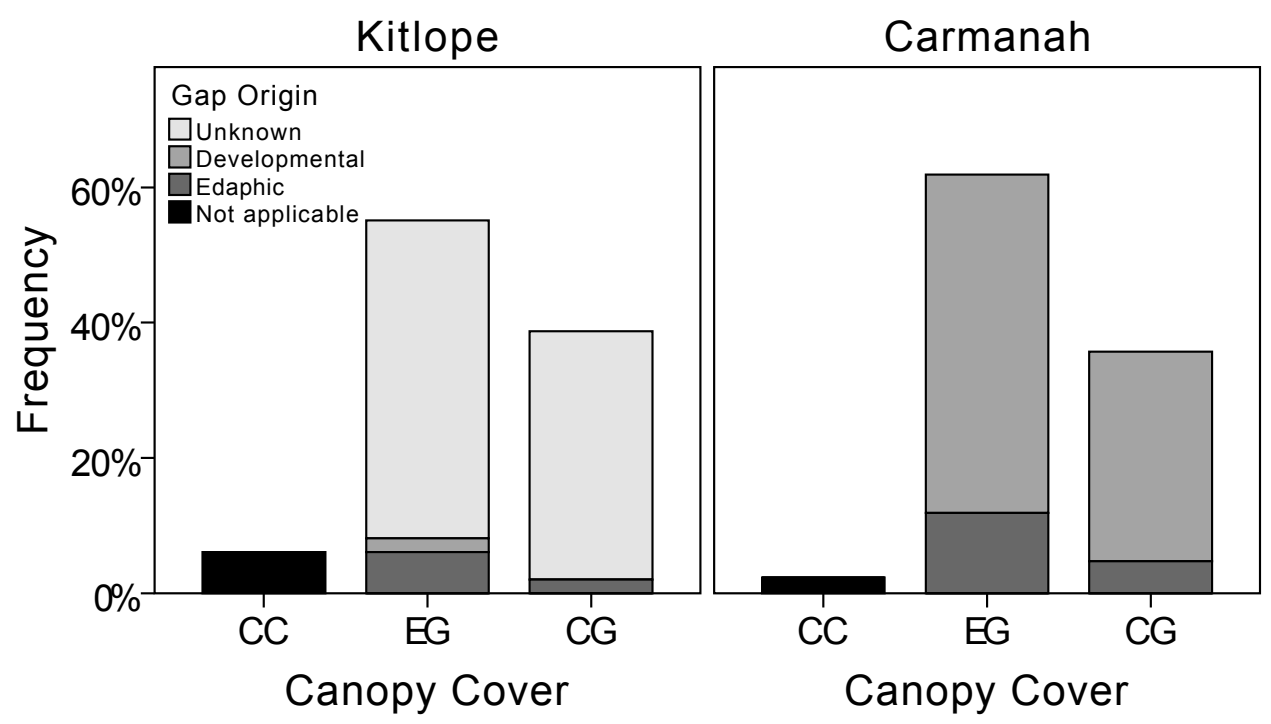

Figure 3 

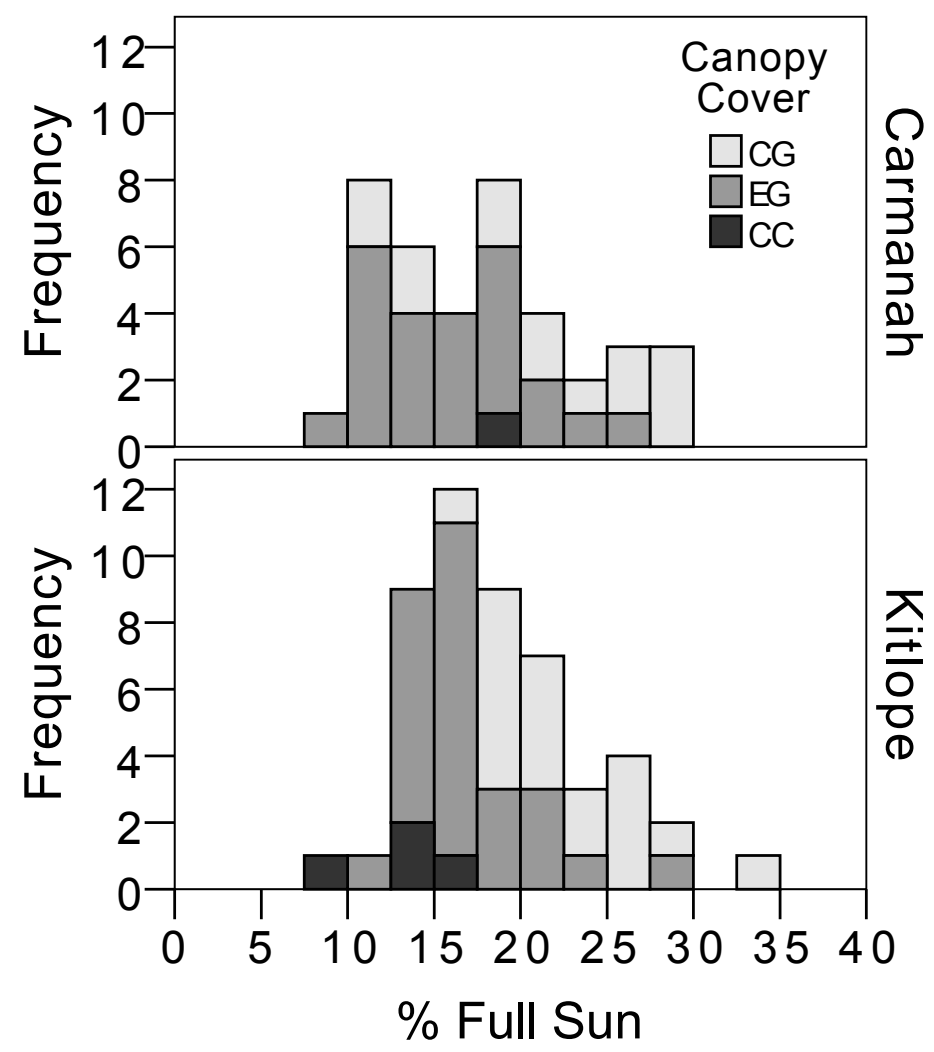

Figure 4. 


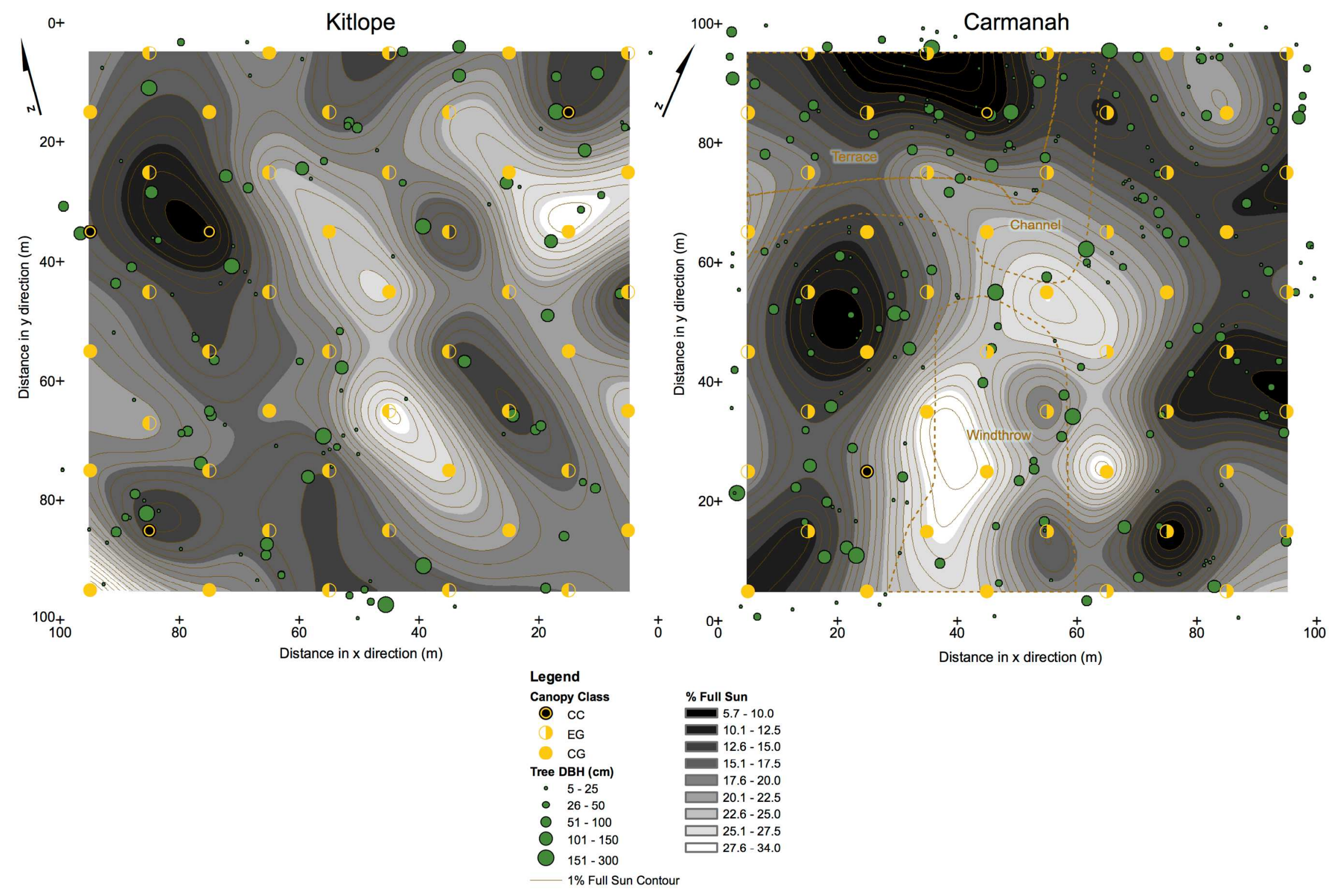

Figure 5. 


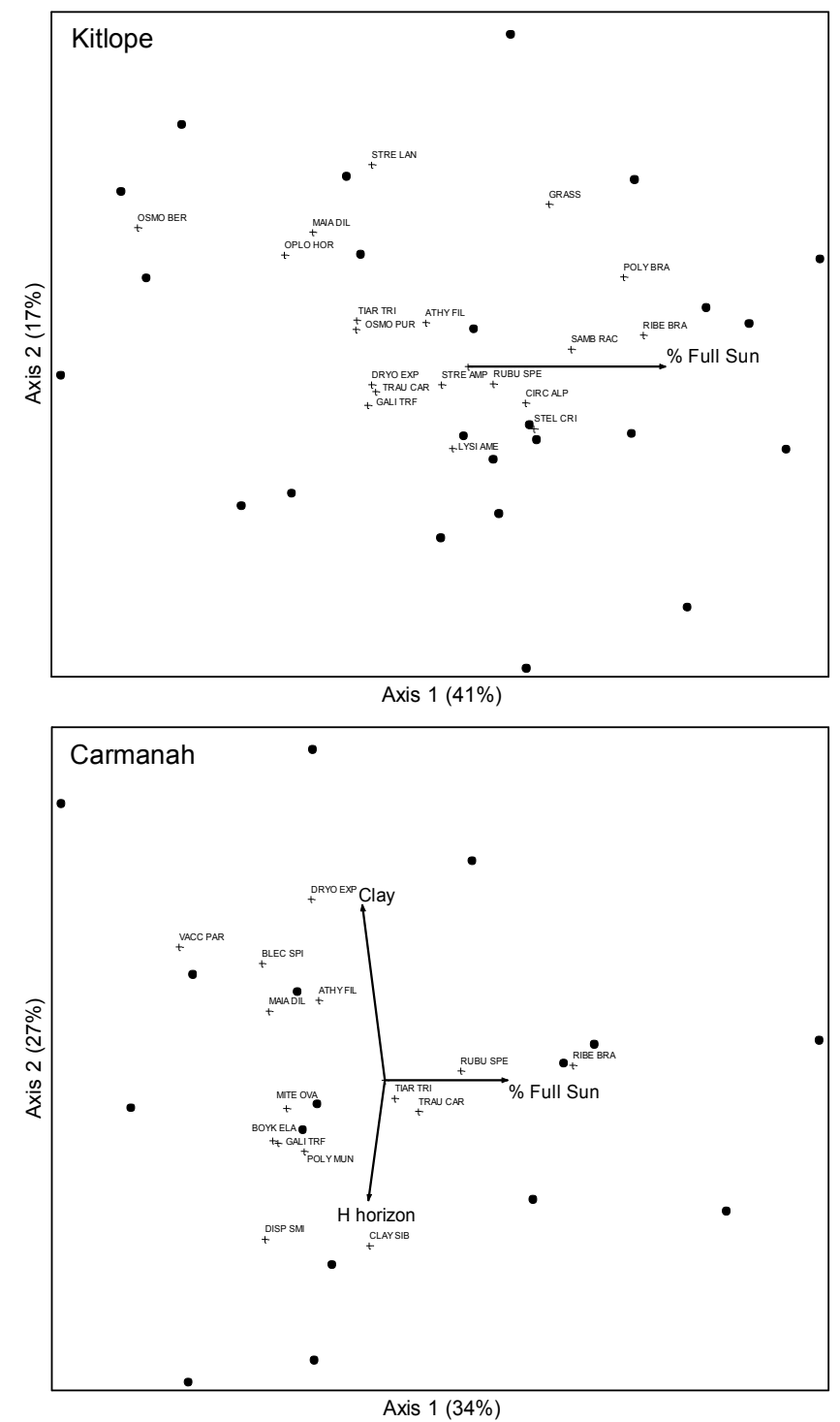

Figure 6. 


\section{Supplementary Material}

Giesbrecht et al. 2017. Overstory structure drives fine-scale coupling of understory light and vegetation in two temperate rainforest floodplains. Canadian Journal of Forest Research. DOI: 10.1139/cjfr-2016-0466

\section{S1. Sampling design}

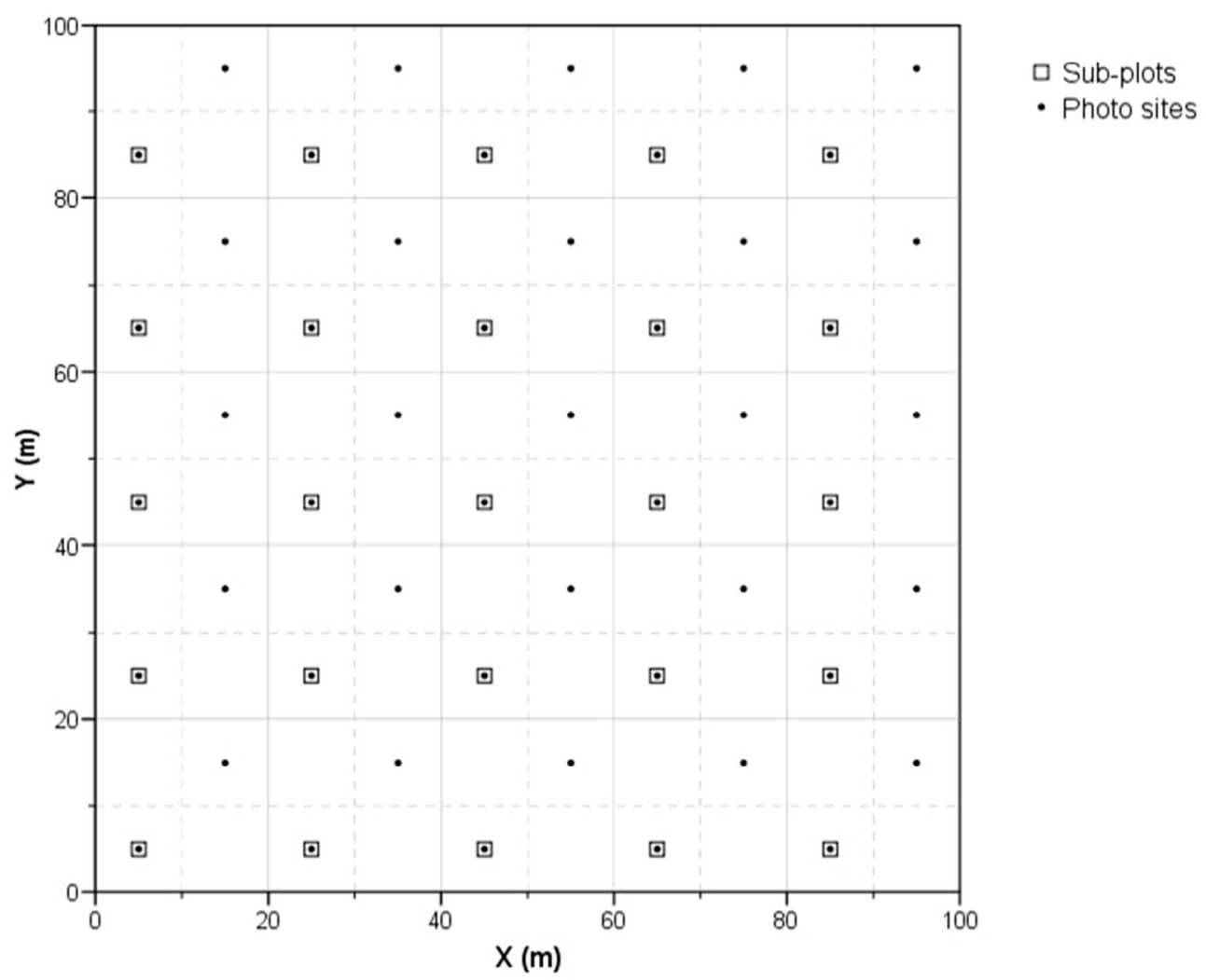

Figure S1. Plan view of sampling layout for subplots and photo sites in the one-hectare macroplots. 


\section{S2. Snag diameter distributions}

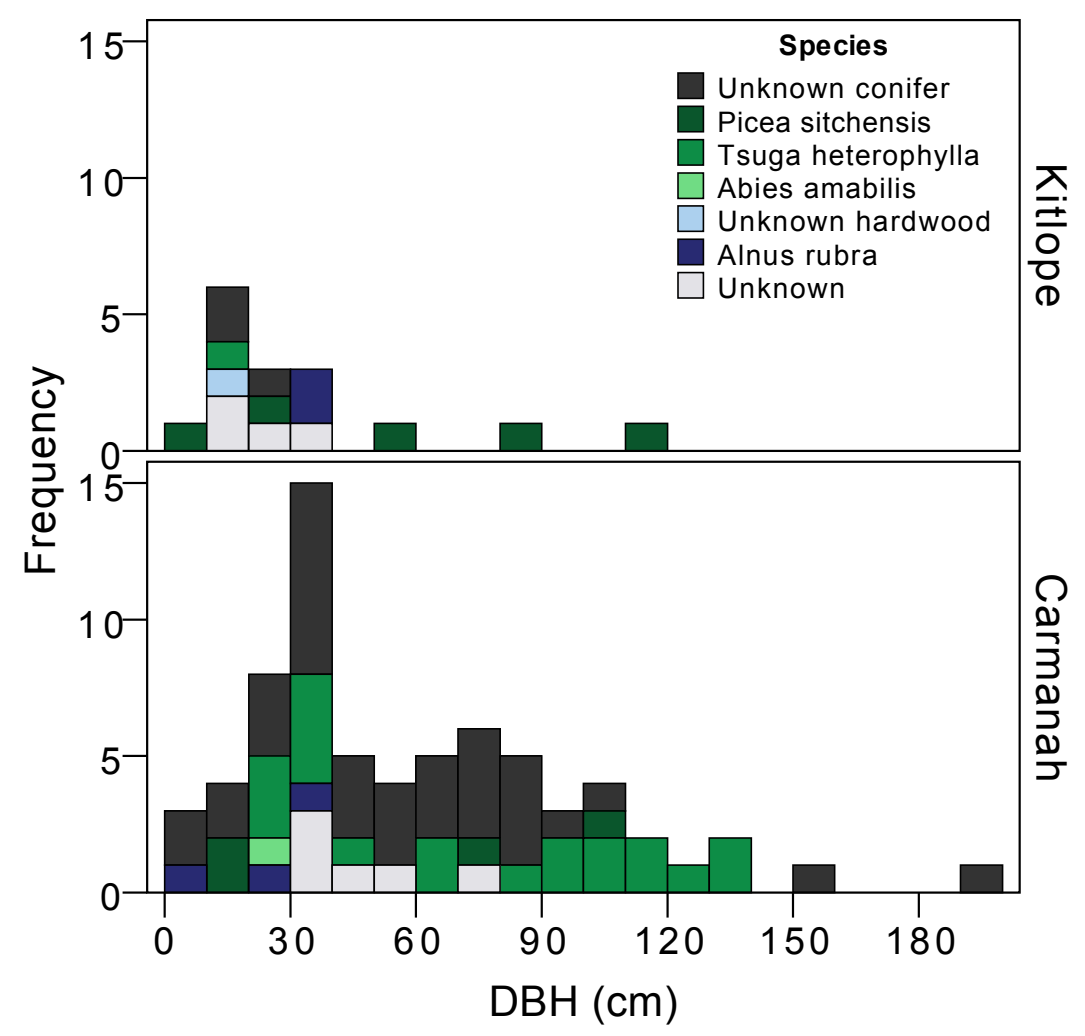

Figure S2. Diameter (DBH) distributions for snags at Kitlope and Carmanah.

\section{S3. Species cover variations along ordination axes}

In some circumstances, it can be misleading to interpret a linear correlation coefficient of species abundance over a compositional or environmental gradient, particularly in the absence of a scatterplot (McCune and Grace 2002). A number of features common to community datasets can make a linear correlation coefficient misleading either by under-representing a relationship that exists (nonlinear response, solid response curve, and outliers) or over-representing one that does or does not exist (zero truncation and outliers). We have attempted to avoid such interpretation 
errors by examining overlays and scatter plots for each species and environmental variable on the ordination axes.

For Kitlope, examination of overlay-scatter plot graphs in PC-ORD revealed that several additional species increase (Sambucus racemosa ssp. pubens, Polystichum braunii, Rubus spectabilis, and Stellaria crispa) or decrease (Galium triflorum, Osmorhiza berteroi, Tiarella trifoliata) along axis 1 , but their responses are nonlinear or obscured by outliers, hence the rather low $r$ values for linear correlations. Oplopanax horridus shows signs of a threshold along axis 1 (in addition to the fairly strong linear correlation) with most occurrences and higher abundances in the lower two thirds of the axis.

At Carmanah, a few species show relationships with axis 1 that are not well captured by the linear correlation coefficients, either due to nonlinearities or outliers. For example, Galium triflorum and Mitella ovalis are only - but not always - present in the darker half of the axis 1 distribution.

\section{S4. Canopy openness and light transmission compared to other forests}

Median site openness (highly correlated with light transmission) at Kitlope and Carmanah $(\sim 11 \%)$ appears to be higher than the median openness of upland old-growth on the wetter west side of Vancouver Island $(\sim 7.5 \%)$ and similar to the median openness on the drier east side of Vancouver Island (by visual comparison to boxplots of Frazer et al. 2000). Median percentage light transmission at Kitlope and Carmanah is higher than reported for most streamside, midslope or hillslope forests sampled in Oregon by Sarr and Hibbs (2007). Roburn (2003) reported mean $5 \%$ full sun transmission in each of two Picea sitchensis floodplain forests in the Seymour 
Valley of southwest British Columbia - substantially less than we have reported for Kitlope or Carmanah, potentially reflecting differences in stand development stage and the volume of subcanopy trees. Mean percentage full sun transmission (18-19\%) in our study is greater than reported for a range of temperate and tropical forest studies (Canham et al. 1990, Nicotra et al. 1999, Lhotka and Loewenstein 2006), which have mean values between 0.5 and $7.0 \%$ total transmission. Mean percentage full sun is similar to the sub-boreal (18.0\%), sub-alpine (19.0\%), and northern temperate (16.0\%) stands of old-growth in northern British Columbia (Bartemucci et al. 2002). By contrast, mean light transmission at Carmanah and Kitlope is markedly lower than reported for a number of old-growth boreal forests in Quebec (27\%; Bartemucci et al. 2006) and northern BC (26.7\%; Bartemucci et al. 2002). 


\section{References for Supplementary Material}

Bartemucci, P., D.K. Coates, K.A. Harper, and E.F. Wright. 2002. Gap disturbances in northern old-growth forests of British Columbia, Canada. J. Veg. Sci. 13: 685-696.

Bartemucci, P., C. Messier, and C. Canham. 2006. Overstory influences on light attenuation patterns and understory plant community diversity and composition in southern boreal forests of Quebec. Can. J. For. Res. 36: 2065-2079.

Canham, C.D., J.S. Denslow, W.J. Platt, J.R. Runkle, T.A. Spies, and P.S. White. 1990. Light regimes beneath closed canopies and tree-fall gaps in temperate and tropical forests. Can. J. For. Res. 20: 620-631.

Frazer, G.W., J.A. Trofymow, and K.P. Lertzman. 2000. Canopy openness and leaf area in chronosequences of coastal temperate rainforests. Can. J. For. Res. 30: 239-256.

Lhotka, J.M. and E.F. Loewenstein. 2006. Indirect measures for characterizing light along a gradient of mixed-hardwood riparian forest canopy structures. For. Ecol. Manage. 226: 310-318.

McCune, B., and J.B. Grace. 2002. Analysis of ecological communities. MjM Software Design, Gleneden Beach, Oregon.

Nicotra, A.B., R.L. Chazdon, and S.V.B. Iriarte. 1999. Spatial heterogeneity of light and woody seedling regeneration in tropical wet forests. Ecology, 80: 1908-1926.

Roburn, A. 2003. Light transmission and understory vegetation in two old-growth riparian stands: a study in spatial pattern. MRM research project, Simon Fraser University, Burnaby, BC. Report No. 331.

Sarr, D.A. and D.E. Hibbs. 2007. Multiscale controls on woody plant diversity in western Oregon riparian forests. Ecol. Mono. 77: 179-201. 